\title{
The Use of SPME-GC-MS IR and Raman Techniques for Botanical and Geographical Authentication and Detection of Adulteration of Honey
}

\author{
Nefeli Sofia Sotiropoulou (D, Marinos Xagoraris (D), Panagiota Kyriaki Revelou (D), Eleftheria Kaparakou, \\ Charalabos Kanakis (D), Christos Pappas and Petros Tarantilis *id
}

Citation: Sotiropoulou, N.S.

Xagoraris, M.; Revelou, P.K.;

Kaparakou, E.; Kanakis, C.; Pappas,

C.; Tarantilis, P. The Use of

SPME-GC-MS IR and Raman

Techniques for Botanical and

Geographical Authentication and

Detection of Adulteration of Honey.

Foods 2021, 10, 1671. https://

doi.org/10.3390/foods10071671

Academic Editor:

Theodoros Varzakas

Received: 1 July 2021

Accepted: 15 July 2021

Published: 20 July 2021

Publisher's Note: MDPI stays neutral with regard to jurisdictional claims in published maps and institutional affiliations.

Copyright: (c) 2021 by the authors Licensee MDPI, Basel, Switzerland. This article is an open access article distributed under the terms and conditions of the Creative Commons Attribution (CC BY) license (https:// creativecommons.org/licenses/by/ $4.0 /)$
Laboratory of Chemistry, Department of Food Science and Human Nutrition, School of Food and Nutrition Sciences, Agricultural University of Athens, Iera Odos 75, 11855 Athens, Greece; nefsot@aua.gr (N.S.S.); mxagor@yahoo.gr (M.X.); p.revelou@aua.gr (P.K.R.); el.kaparakou@gmail.com (E.K.); chkanakis@aua.gr (C.K.); chrispap@aua.gr (C.P.)

* Correspondence: ptara@aua.gr; Tel.: +30-2105294262

\begin{abstract}
The aim of this review is to describe the chromatographic, spectrometric, and spectroscopic techniques applied to honey for the determination of botanical and geographical origin and detection of adulteration. Based on the volatile profile of honey and using Solid Phase microextraction-Gas chromatography-Mass spectrometry (SPME-GC-MS) analytical technique, botanical and geographical characterization of honey can be successfully determined. In addition, the use of vibrational spectroscopic techniques, in particular, infrared (IR) and Raman spectroscopy, are discussed as a tool for the detection of honey adulteration and verification of its botanical and geographical origin. Manipulation of the obtained data regarding all the above-mentioned techniques was performed using chemometric analysis. This article reviews the literature between 2007 and 2020.
\end{abstract}

Keywords: honey authentication; SPME; GC-MS; IR; Raman; chemometrics; botanical and geographical origin; adulteration

\section{Introduction}

Honey is a sweet and viscid natural product produced by bees (Apis mellifera L.) either from the nectar of flowers (blossom honey) or from secretions of the living parts of plants other than flowers or is a product of excretions of plant-sucking insects (honeydew honey) [1,2]. It is characterized as a natural sweetener and its consumption is increasing worldwide due to its important role in the human diet, as it is endowed with many beneficial health properties [3,4]. It is estimated that more than 1.2 million tons of honey are produced per year; thus, it is characterized by a high economic importance [5]. The nutritional and economic value of honey is due to its unique composition. Honey contains sugars, water, proteins, organic acids, vitamins, minerals, pigments, phenolic and volatile compounds, and some solid particles [6,7].

The composition of honey depends on collection season, climate conditions, proximity to the forest, characteristics of soil which determine melliferous flora, method of storage, processing, and practices of beekeeping, and even interactions between chemical compounds and enzymes $[3,8,9]$. However, the aroma and taste of honey, owed to the volatile compounds, are dependent mainly on the botanical and floral origin of honey [9-12].

Honey authenticity concerns its origin and the mode of its production, which is important both for consumers and producers $[7,13]$. The authentication of honey is also significant for commercial and health related reasons. Honey gains worldwide popularity among health-conscious consumers and also by consumers who demonstrate great interest in the origin and quality of the product $[3,14,15]$. Therefore, honey labelling in order to avoid unfair competition and adulteration has become a mandatory demand [16,17]. 
Nowadays, botanical and geographical originality of honey is a major concern among authorities in order to ensure its quality and authenticity, by imposing specific standards that allow honey to be competitive in the market $[3,16]$. Traditionally, identification of botanical and geographical origin of honey is performed by melisopalinological analysis $[18,19]$. This analysis is a time and cost-consuming process which cannot ensure reliable characterization of the honey floral source since it strongly depends on the capability of the analyzer $[20,21]$. Therefore, it is important to complement this analysis with other, more analytical techniques (physicochemical, organoleptic, chromatographic etc.), or replace it with them. During the past decades, several studies focused on gas chromatography (GC) in order to determine the volatile profile of honey $[3,9,11,20,22-26]$. The characteristic chemical fingerprint generated by volatile compounds is of major importance regarding consumers' choice since it provides information about the botanical and geographical origin of honey [27].

Gas chromatography with mass spectrometry (GC-MS) is suggested as a convenient, appropriate technique for the determination of volatile compounds with high precision [28-36]. GC-MS provides the separation of volatile components of honey sample and then the necessary information for their identification [2]. Various techniques are used to collect the volatile fraction from a sample, among them Solid Phase microextraction (SPME) has been reported as the most preferable [32,37,38]. SPME is adopted since it is rapid, easy, and effective, and can also be applied to a small sample amount [36,38-46]. SPME is also eco-friendly, cheap, sensitive, selective, versatile, and possibly automated $[39,41,43]$. The chemical profile of honey obtained after GC-MS analysis is usually complex. Consequently, its interpretation requires the use of specific methods in order to simplify results and to give a final report which facilitates honey classification according to its geographical and botanical origin. In this regard, chemometrics is considered a valuable tool of data analysis, widely used by many researchers [47,48].

Another main topic concerning the beekeeping sector, the honey industry, and researchers is the adulteration of honey. According to European Union regulations, the addition or removal of any kind of honey substance is illegal [49]. Honey adulteration is achieved by adding lower quality honey and artificial adulterants [50]. Honey's health benefits, and its unique flavor and aroma make it more expensive in comparison to other sweeteners. Therefore, in an attempt to reduce production costs and simultaneously increase profit, honey is a product usually subjected to adulteration $[9,15,51]$. Starch and inverted syrup fed to bees, addition of sugars such as high fructose, glucose, and saccharose syrups, and low-quality honey added to high-priced honey are considered the most common ways of honey adulteration [15,52]. Honey adulteration can occur in any step of production or processing. It is also difficult to detect due to the fact that the adulterated honey is similar to the pure one [53]. Moreover, the classical methods that certify honey quality, such as physicochemical analyses, are incapable of detecting adulteration accurately. Thus, it is essential to develop and adopt a new process for honey quality control. For the aforementioned reasons, many analytical techniques have been applied, characterized by high effectiveness, accuracy, and sensitivity for the detection of honey adulteration [9].

In recent years, vibrational molecular spectroscopy techniques such as infrared (IR) and Raman are used to identify and quantify the chemical composition of various food products with flexibility, efficiency, and low cost [54]. These techniques also provide an easy, reliable, environmentally friendly, non-destructive, and prompt way for honey quality control. In most cases, there is a combination of spectroscopic techniques and chemometrics allowing the visualization and better classification of the samples [16,50,51,55-59]. Despite the fact that advanced and accurate analytical techniques have been performed for honey authentication, there are studies that focus on the development of an authentication model using simple physical and chemical parameters or spectral data [60-62]. Therefore, this quest has led to the application of advantageous spectroscopic techniques (IR, Raman) in order to develop this model for botanical and geographical characterization $[9,54,63,64]$. 
The combination of these spectroscopic techniques with chemometrics provides satisfactory discrimination and rapid first-line classification of honey based on its botanical and geographical origin $[9,16,63,65]$.

In order to analyze these complex data (e.g., spectral-chemical data sets), chemometrics methods are required, as mentioned before. Chemometric tools are applied in targeted and non-targeted approaches for the identification of food adulteration or verification of their botanical or geographical origin [18,53,55,66-70]. The most common unsupervised methods, used for exploratory analysis in food authentication, include honey authentication, are principal component analysis (PCA) and hierarchical clustering analysis (HCA) $[28,59,71-75]$. For discrimination and classification purposes, linear discriminant analysis (LDA), partial least squares discriminant analysis (PLS-DA), orthogonal partial least squares discriminant analysis (OPLS-DA), k-nearest neighbor (k-NN), principal component regression (PCR), multiple linear regression (MLR), or partial least squares regression (PLS-R) were commonly performed as supervised methods [28,57,72-74,76,77]. For the botanical and geographical characterization of honey, most of the aforementioned chemometric tools have been reported such as PCA, HCA, LDA, and PLS-R, either combined with GC-MS [47,48,77-79] or with IR and Raman spectroscopy $[9,16,54,56,63,80]$. In the case of honey adulteration, the same statistical techniques as above were used combined with spectroscopic analysis (IR and Raman) [50,55,59,64].

The aim of this work was to present a review (period of 2007-2020) of SPME-GC-MS and spectroscopic techniques in combination with chemometrics for honey authentication. In addition, spectroscopic techniques (IR, Raman) combined with chemometric analysis for the investigation of honey adulteration are briefly discussed.

\section{Honey Volatile Compounds Analysis Using SPME-GC-MS}

Honey aroma depends on qualitative and quantitative composition of the volatile compounds; it is one of its most important properties as mentioned before and is considered a significant topic of study. The volatile profile of honey could reveal its botanical and geographical origin; thus, a false characterization can be avoided. Since botanical and geographical classification of honey is an important issue, chromatographic analytical techniques have been developed aimed at its chemical characterization and consequently its classification.

Many extraction methods that have been used to collect honey volatile compounds, combined with GC-MS analysis in order to provide information for honey authenticity $[3,9,10,22,81]$, require consumables, solvents, and a lot of time [41]. Particularly, the solvent extraction has been employed for honey characterization, due to its simplicity and to the fact that is applied without heat. However, this method can solubilize also nonvolatile compounds and the solvents can con-elude with analytes [41,82]. Moreover, for the isolation of honey's volatile compounds, simultaneous steam distillation-extraction has been reported, with the intention of avoiding sugar interference. The main disadvantage of this method is the presence of non-characteristic compounds in honey samples due to exposure to heat $[22,41]$. In addition, another commonly used method to extract the volatile compounds of honey is purge and trap thermal desorption, providing high sensitivity for fractionation of high-volatility compounds, the absence of extended heating times, and the reproducibility associated with a totally automated system [11,12,18,23-26,83]. However, this method requires specific and expensive devices [41].

On the other hand, SPME sampling technique is solvent-free, inexpensive, rapid, and simple. It is ideal for the collection of honey volatile compounds since it provides high sensitivity along with effectiveness and requires a small amount of untreated sample [38,41]. However, the adsorption selectivity of the fiber and its discrimination between components of must be considered for quantitative determination of volatile compounds [84]. 


\subsection{Botanical Characterization of Honey by SPME-GC-MS}

Volatile compounds of honey are related to the floral origin and could be used as biomarkers. SPME followed by GC-MS for determining the volatile profile of honey are used as a tool for the botanical characterization of several different types of honeys $[8,11,14,21,27,37,85-88]$.

Thus, in unifloral honeys (linden, rape, acacia, and sunflower) from Romania, 98 volatile compounds were detected and classified in seven main classes. Commonly detected compounds in all tested honeys were $\beta$-damascenone, cis-linalool oxide, hotrienol, $p$-cuminalaldehyde, nonanoic acid, phenylethyl alcohol, benzyl alcohol, and benzaldehyde. These compounds can be considered as specific markers for each type of honey. However, in the case of acacia honey, the new specific markers were 8-hydroxylinalool, 2-furfuralaldehyde, 2-hexen-1-ol, 2-hydroxycyclopent-2-en-1-one, 2-phenylethyl isothiocyanate, 2-phenylpropenal, 5-hydroxymethylfurfural, decanal, dimethyl palmitamine, hotreniol, lilac aldehyde $\mathrm{C}$, lilac aldehyde $\mathrm{D}$, linalool oxide, myrtenal, octanoic acid, oleic acid, and pinocarvone. On the other hand, marker compounds for sunflower honey were 3-furfural aldehyde, (3,3-dimethylcyclohexylidene) acetaldehyde, 1,3,3-trimethylcyclohex-1-ene-4carboxaldehyde, $p$-menthan-3-one, endo-borneol, menthol, myrtenol, verbenone, isopiperitone, $p$-cymen-7-ol, eugenol, $\beta$-calarene, cis-linalool oxide (furanoid), and hotrienol. The specific markers for linden honey were the compounds 6-allyl-o-cresol, allylphenylsulfide, butanoic acid, 3,6-dimethyl-4,5,6,7-tetrahydro-1-benzofuran, 1-methyl-4-(1-methylpropyl)benzene, trans-dihydrocarvone, $o$-methylacetophenone, isoneral, isopropyl benzene, geranic acid, sabinene, teresantalol, 2-undecenal, $p$-cymene, and myrtenyl acetate, while rape honey as characterized by the presence of 3-methylpentanol, pentanoic acid, ethyl 2-hydroxy-4-methylbenzoate, trans-linalool oxide, $\alpha, \alpha, 4$-trimethylbenzyl alcohol, lilac alcohol C, 3-phenyl propanol, dihydro-5-propyl-2(3H)-furanone, ethyl decanoate, ethyl 3-hydroxytridecanoate, ethyl dodecanoate, 2,2,4-trimethyl-1,3-pentanediol diisobutyrate, ethyl palmitate, ethyl oleate, ethyl benzoate, and 3-methylbutanol [8].

Volatile compounds of unifloral Thymus capitatus, Thymelaea hirsute, and Tolpis virgata honeys from Palestine were determined also by HS-SPME-GC-MS (headspace-solid-phase microextraction-gas chromatography-mass spectrometry). Aldehydes, organic acids, phenols, and alcohols were present in all the honeys. Chemical markers for Thymus capitatus honey were 1,3-diphenyl-2-propanone, (3-methylbutyl) benzene, 3,4,5-trimethoxybenzaldehyde, 3,4-dimethoxy benzaldehyde vanilline, and thymol. In the case of Thymelaea hirsuta honey, benzene propanol, benzylalcohol, nonanol, hexanol, and 4-methoxyphenol were its characteristic compounds. Tolpis virgata honey was characterized by 3,5-dihydroxytoluene and tridecane [86].

Monofloral (rape, caraway, and white clover) and polyfloral honey from Lithuania were studied. The chemical classes of the volatile compounds were the same for all studied samples, but their botanical classification was achieved through qualitative and quantitative differences between these classes. Rape honey was distinguished by high percentage of $p$-cymenene, while a high amount of benzaldehyde characterized the caraway honey [12].

Croatian honey samples of Paliurus honey were dominated by nonanal, four isomers of lilac aldehyde, decanal, methyl nonanoate, hexanoic, and 2-ethylhexanoic acids [27].

By performing also SPME-GC-MS, the most important components of Ulmo honey flavor were benzaldehyde, $\beta$-damascenone, octane, nonanal, 4-methoxybenzaldehyde, isophorone, lyrame, and 4-vinylanisole [14].

The volatile profile of three endemic different blossoms of Brazil were determined. Aromatic aldehydes of juazeiro honey, sulfur compounds and ketones of jurema honey, and volatile acids of velame branco could be considered as markers of "blossom type" origin [21].

Different varieties of popular Polish honeys were studied by Plutowska et al. [37]. Heather honey was characterized by the presence of 3,4,5-trimethylphenol, phenylacetic acid, $\beta$-damascenone, benzoic acid, and isophorone (3,5,5-trimethyl-2-cyclohexen-1-one), and linden honey by dimethylstyrene. In the case of acacia honey, characteristic compounds 
were benzaldehyde, nonanal, and phenylacetaldehyde, and for honey-dew honey were 2,3-butanethiol and acetic acid isomers.

Buckwheat honey from Poland was characterized by furfural, 2- and 3-methylbutanoic acid, and 2- and 3-methylbutyraldehyde [26], while 3-methylbutanoic acid also presented at high levels in the buckwheat honeys from Italy and east Europe. Thus, 2-methylbutanal and phenylacetaldehyde could be considered as botanical markers [87].

In rape honey, benzoic acid and its ethyl ester were considered the most characteristic and abundant compounds [8,37]. Other compounds suggested as markers for rape honey include benzoic alcohol [37], 1-pentanol-3-methyl, and 1-butanol-3-methyl [8].

In another study by Špánik et al. [88], selected chiral volatile compounds of acacia, chestnut, linden, rapeseed, orange, and sunflower honeys were determined for botanical characterization using SPME-GC-MS techniques. Specially, rapeseed honey was characterized by the variation in enantiomer ratio of linalool. In cases of acacia and oranges honeys, differentiation was achieved by enantiomer ratios of lilac aldehydes. Finally, a different enantiomer ratio of 4-terpineol was found in sunflower honey.

During the past decade, it has been noted that SPME-GC-MS fingerprinting of honey volatiles combined with chemometrics can be considered as non-time and of high potential combination also for routine analyses of honey for their botanical characterization.

Differentiation of citrus and thyme honey produced in Greece was achieved using SPME-GC-MS. Chemometric models, namely principal components analysis (PCA), orthogonal partial least squares-discriminant analysis (OPLS-DA), OPLS- hierarchical cluster analysis (OPLS-HCA), and soft independent modelling of class analogy (SIMCA) were used to analyze results. Lilacaldehyde, limonene, methyl anthranilate, and 1- $p$-menthen9-al isomers were biomarkers for citrus honey. For thyme honey, phenylacetaldehyde, 3-hydroxy-4-phenyl-2-butanone, 3-hydroxy-1-phenyl-2-butanone, 1-phenyl-2,3-butanedione, and 3-hydroxy-4-phenyl-3-buten-2-one were the compounds' biomarkers that allowed its discrimination from citrus honey (Figure 1) [47].

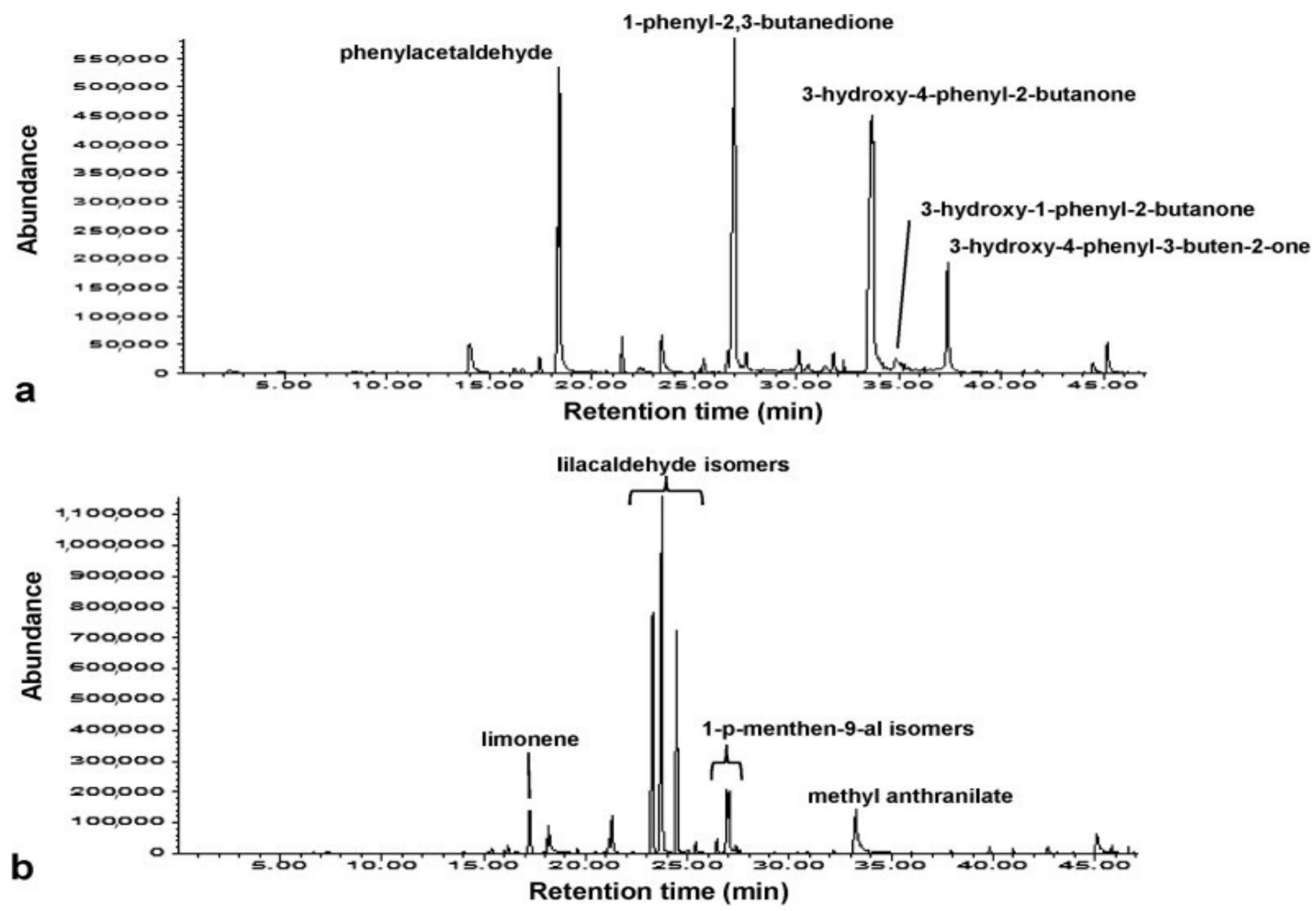

Figure 1. Representative chromatograms of thyme (a) and citrus (b) honey samples extracted performing HS-SPME. Compounds that serve as biomarkers for their discrimination are indicated. Reprinted with permission from ref. [47]. Copyright 2017 Copyright Elsevier B.V. 
A "leave-one-out" cross validation procedure proved the stability of the model concerning the botanical origin of thistle honey from Italy. The volatile compounds detected in all the analyzed thistle honeys were decanal, nonanal, furfural, 3,6-dimethyl-2,3,3a,4,5,7ahexahydrobenzofuran, benzaldehyde, hotrienol, $\alpha$-linalool, lilac aldehyde (isomer IV), phenylacetaldehyde, 4-oxoisophorone, benzyl alcohol, 2-phenylethanol, methyl anthranilate, octanoic, and nonanoic acids. This developed model was based on the valuation of the relative amounts of the above compounds. Each thistle honey was removed one at a time from the initial model, then the model was rebuilt, and the honey sample removed was classified as the new model [17].

Corsican chestnut catkins and chestnut grove honeys were also characterized from volatile compounds to provide information for their botanical authenticity, using PCA and cluster analysis (CA) as statistical methods. It was found that the main compounds of chestnut catkins were acetophenone, methyl salicylate, linalool, and nonanal, and 2-aminoacetophenone, acetophenone, benzaldehyde, nonaic and octanoic acids, and 3-furaldehyde were the dominant compounds of chestnut grove honeys [89].

In a study by Karabagias et al. [60], Greek unifloral honeys (thyme, pine, fir, and orange blossom) were characterized according to the botanical origin using headspace (HS)SPME-GC-MS and Linear Discriminant Analysis (LDA). Results showed that 30 volatile compounds of different classes classified the different unifloral honeys, by achieving a classification rate of $84.0 \%$ using the leave one out cross validation method. In another study by Karabagias et al. [77], volatiles for the authentication of monofloral honey coming from different varieties of Greek honey (citrus, fir, pine, and thyme) were determined. Specifically, only nine volatile compounds were used for the botanical classification ( $\alpha$-4-dimethyl-3-cyclohexene-1-acetaldehyde, dill ether, acetic acid ethyl ester, octanoic acid ethyl ester, methylanthranilate, 2,2,4,6,6-pentamethyl-heptane, phenylacetaldehyde, cis-linalool oxide and lilac aldehyde (isomer III)) using PCA, CA, LDA, multivariate analysis of variance (MANOVA), stepwise linear discriminant analysis (SLD), and k-nearest neighbor analysis $(\mathrm{k}-\mathrm{NN})$.

Thirteen different honey types from four different botanical origins (heather, raspberry, rape, and alder-buckthorn) from Estonia were studied. Agglomerative hierarchical clustering and correspondence analysis showed that none of the identified volatile compounds were determined solely at one blossom honey type. However, in the case of heather honey, isophorone and 2-methylbutyric acid were identified as characteristic compounds [38].

A total of 100 samples from six different varieties (Acacia nilotica, Acacia seyal, Ziziphus spina-christi, Amaranthus graecizan, Eucalyptus spp., and multifloral) of Sudan were studied. Choosing the twenty most abundant and characteristic volatile compounds and by applying multivariate analysis (HCA, PCA and partial least-squares regression, PLSR), the honey samples were clearly distinguished based on the floral type [79].

Da Costa et al. [21] characterized different monofloral honeys produced in the Brazilian semiarid region based on their volatile profile. It was suggested that linalool for malícia honey, $D$-sylvestrene for chanana honey, rose oxide for algaroba honey, and benzenethanol for angico honey are the markers for botanical sources. This variation was visualized and confirmed by PCA.

Kortesniemi et al. [13] determined the odor active compounds of Finnish honeys such as buckwheat, cloudberry-bog, lingonberry, sweetclover, willowherb, and multifloral honeys, applying SPME-GC-MS-O (olfactometry) and statistical methods (PCA, PLS). They reported that odor active compounds of honeys showed variation in Finnish honeys from different floral sources.

A total of 14 rare lacy phacelia (Phacelia tanacetifolia Benth.) honey samples from Poland were analyzed. According to PCA and hierarchical-tree clustering (HTC), it was found that hexan-1-ol and lavender lactone were characteristic biomarkers for authentication of rare lacy phacelia honey [4].

The botanical source of heather honey from northwest of Iberian Peninsula was evaluated by volatile compounds analysis combined with PCA and Spearman's rank 
correlation. There were 58 volatile compounds identified, including terpenoids, alcohols, benzene compounds, furan derivatives, and aldehydes. The marker volatile compound of heather honey was hotrienol. Moreover, phenylacetaldehyde and cis-linalool oxide were found at high amounts [90]. Table 1 shows a summary of the literature survey based on the volatile compounds of honey as botanical markers.

Table 1. Employment of SPME-GC-MS technique for the determination of volatile compounds for botanical characterization of unifloral honeys.

\begin{tabular}{|c|c|c|c|}
\hline Floral Origin & $\begin{array}{l}\text { Volatile Compounds as Markers for Botanical } \\
\text { Source }\end{array}$ & Geographical Origin & References \\
\hline \multirow[t]{3}{*}{ Acacia } & $\begin{array}{l}\text { 8-Hydroxylinalool, 2-furfural-aldehyde, } \\
\text { 2-hexen-1-ol, 2-hydroxycyclopent-2-en-1-one, } \\
\text { 2-phenylethyl isothiocyanate, 2-phenylpropenal, } \\
\text { 5-hydroxymethylfurfural, decanal, dimethyl } \\
\text { palmitamine, hotreniol, lilac aldehyde C, lilac } \\
\text { aldehyde D, linalool oxide, myrtenal, octanoic } \\
\text { acid, oleic acid, pinocarvone }\end{array}$ & Romania & [8] \\
\hline & Benzaldehyde, nonanal, phenylacetaldehyde & Poland & [37] \\
\hline & $\begin{array}{c}\left(2 S, 2^{\prime} R, 5^{\prime} R\right) \text { - Lilac aldehyde } \mathrm{B},\left(2 S, 2^{\prime} R, 5^{\prime} S\right) \text {-lilac } \\
\text { aldehyde } \mathrm{C} \text {, hotrienol }\end{array}$ & $\begin{array}{l}\text { Slovakia, Czech Republic, } \\
\text { Romania, Germany, Serbia, } \\
\text { Georgia, Poland, Moldova }\end{array}$ & [88] \\
\hline \multirow[t]{3}{*}{ Buckwheat } & $\begin{array}{l}\text { Furfural, 2-methylbutanoic acid, 3-methylbutanoic } \\
\text { acid, 2-methylbutyraldehyde, } \\
\text { 3-methylbutyraldehyde }\end{array}$ & Poland & [37] \\
\hline & $\begin{array}{l}\text { 3-Methylbutanoic acid, 2-methylbutanal, } \\
\text { phenylacetaldehyde }\end{array}$ & Italy, east Europe & {$[87]$} \\
\hline & $\begin{array}{l}\text { 3-Methylbutanal, butanoic acid, } \\
\text { 3-hydroxy-4,5-dimethyl-2(5H)-furanone, } \\
\text { phenylacetaldehyde }\end{array}$ & Finland & [13] \\
\hline \multirow[t]{2}{*}{ Chestnut } & trans-Linalool oxide, hotrienol, $(R)$-4-terpineol & Italy & [88] \\
\hline & $\begin{array}{l}\text { 2-Aminoacetophenone, benzaldehyde, } \\
\text { acetophenone, nonaic acid, octanoic acid, } \\
\text { 3-furaldehyde }\end{array}$ & Corsica Island & {$[89]$} \\
\hline \multirow[t]{3}{*}{ Citrus } & $\begin{array}{l}\text { Lilac aldehyde, 1-p-menthen-9-al isomers, } \\
\text { limonene, methyl anthranilate }\end{array}$ & Greece & {$[47]$} \\
\hline & Linalool, E-linalool oxide, limonene & Greece & [48] \\
\hline & $\begin{array}{c}\text { 4-Methoxy-benzaldehyde, lilac aldehydes A- D } \\
\text { (isomers I-IV), } \\
\alpha \text {-4-dimethyl-3-cyclohexene-1-acetaldehyde, } \\
\text { 2-cyclohexene-1-propanal, methylanthranilate, } \\
\text { linalool, herboxide (isomer II), cis-linalool oxide, } \\
\text { dill ether }\end{array}$ & Greece & {$[77]$} \\
\hline Citrus aurantium & $\begin{array}{l}\left(2 S, 2^{\prime} R, 5^{\prime} R\right) \text { - Lilac aldehyde } \mathrm{B},\left(2 S, 2^{\prime} R, 5^{\prime} S\right) \text {-lilac } \\
\text { aldehyde } C,\left(2 R, 2^{\prime} R, 5^{\prime} S\right) \text {-lilac aldehyde D }\end{array}$ & Greece, Italy, France & [88] \\
\hline \multirow[t]{2}{*}{ Fir } & $\begin{array}{c}\text { Ethyl hexanoate, ethyl heptanoate, ethyl octanoate, } \\
\text { ethyl nonanoate, ethyl decanoate, ethyl } \\
\text { dodecanoate, ethyl tetradecanoate, } \\
\text { 6-methyl-5-hepten-2-one, } \\
\text { 2-hydroxy-3,5,5-trimethyl- cyclohex-2-en-one, } \\
\text { 1-(2-furanyl)-ethanone, nonane, } \\
\text { (Z)-5-methyl-4-nonene, 3,4,5-trimethyl-phenol, } \\
\text { nonanal }\end{array}$ & Greece & {$[60]$} \\
\hline & Nonanal & Greece & [77] \\
\hline
\end{tabular}


Table 1. Cont.

\begin{tabular}{|c|c|c|c|}
\hline Floral Origin & $\begin{array}{l}\text { Volatile Compounds as Markers for Botanical } \\
\text { Source }\end{array}$ & Geographical Origin & References \\
\hline \multirow[t]{3}{*}{ Heather } & $\begin{array}{l}\text { 3,4,5-Trimethylphenol, phenylic acid, benzoic acid, } \\
\beta \text {-damascenone, isophorone }\end{array}$ & Poland & [37] \\
\hline & Isophorone, 2-methylbutyric acid & Estonia & [38] \\
\hline & Hotrienol & $\begin{array}{c}\text { Northwest of Iberian } \\
\text { Peninsula (Spain, Portugal) }\end{array}$ & [90] \\
\hline \multirow[t]{3}{*}{ Linden } & $\begin{array}{l}\text { 6-Allyl-o-cresol, allylphenylsulfide, butanoic acid, } \\
\text { 3,6-dimethyl-4,5,6,7-tetrahydro-1-benzofuran, } \\
\text { 1-methyl-4-(1-methylpropyl)-benzene, } \\
\text { trans-dihydrocarvone, } o \text {-methylacetophenone, } \\
\text { isoneral, isopropyl benzene, geranic acid, sabinene, } \\
\text { teresantalol, 2-undecenal, } p \text {-cymene, myrtenyl } \\
\text { acetate }\end{array}$ & Romania & [8] \\
\hline & Dimethylstyrene & Poland & [37] \\
\hline & 4-Terpineol & $\begin{array}{c}\text { Slovakia, Czech Republic, } \\
\text { Romania, Hungary, } \\
\text { Moldova }\end{array}$ & [88] \\
\hline \multirow[t]{2}{*}{ Pine } & $\beta$-Thujone, octane & Greece & [60] \\
\hline & 2-Hydroxybenzaldehyde & Greece & [77] \\
\hline \multirow[t]{4}{*}{ Rapessed } & $\begin{array}{c}\text { 3-Methylpentanol, pentanoic acid, ethyl } \\
\text { 2-hydroxy-4-methylbenzoate, trans-linalool oxide, } \\
\text {, } \alpha \text {,4- trimethylbenzyl alcohol, lilac alcohol C, } \\
\text { 3-phenyl propanol, } \\
\text { dihydro-5-propyl-2(3H)-furanone, ethyl decanoate, } \\
\text { ethyl 3-hydroxytridecanoate, ethyl dodecanoate, } \\
\text { 2,2,4-trimethyl-1,3-pentanediol diisobutyrate, } \\
\text { ethyl palmitate, ethyl oleate, ethyl benzoate, } \\
\text { 3-methylbutanol }\end{array}$ & Romania & [8] \\
\hline & $\begin{array}{c}\text { Hexanal, } p \text {-cymene, } 4 \text {-methyloctane, cumene, } \\
\text { 3-caren-2-ol, } \beta \text {-phellandrene, } \\
\text { 4-methyl-2,7-octadiene, } \\
\text { 2,6-dimethyl-3,5,7-octatriene, trans-sabinene } \\
\text { hydrate, verbenone, 1,3,8- } p \text {-menthatriene, } \\
\text {-sec-butyltoluene, } o \text {-anisaldehyde, carvacrol }\end{array}$ & Lithuania & [12] \\
\hline & Benzoic acid, benzyl alcohol & Poland & [37] \\
\hline & $(R)$-Linalool & Slovakia & [88] \\
\hline \multirow[t]{2}{*}{ Sunflower } & $\begin{array}{c}\text { 3-Furfural aldehyde, } \\
\text { (3,3-dimethylcyclohexylidene) acetaldehyde, } \\
\text { 1,3,3-trimethylcyclohex-1-ene-4-carboxaldehyde, } \\
\text {-menthan-3-one, endo-borneol, menthol, } \\
\text { myrtenol, verbenone, isopiperitone, } p \text {-cymen-7-ol, } \\
\text { eugenol, } \beta \text {-calarene, cis-linalool oxide(furanoid), } \\
\text { hotrienol }\end{array}$ & Romania & [8] \\
\hline & 4-Terpineol, trans-linalool oxide & Slovakia, Ukraine & [88] \\
\hline
\end{tabular}


Table 1. Cont.

\begin{tabular}{|c|c|c|c|}
\hline Floral Origin & $\begin{array}{l}\text { Volatile Compounds as Markers for Botanical } \\
\text { Source }\end{array}$ & Geographical Origin & References \\
\hline Thyme & $\begin{array}{l}\text { Formic acid, hexadecanoic acid, 1-octanol, } \\
\text { 1-hydroxy-2-propanone, decane }\end{array}$ & Greece & {$[60]$} \\
\hline Thymus capitatus & $\begin{array}{c}\text { 1,3-Diphenyl-2-propanone, } \\
\text { 1-butyl-3-methylbenzene, 3,4,5-trimethoxy } \\
\text { benzaldehyde, 3,4-dimethoxy benzaldehyde, } \\
\text { vanilline, thymol }\end{array}$ & Palestine & [86] \\
\hline Thymus capitatus & $\begin{array}{l}\text { Phenylacetaldehyde, 1-phenyl-2,3-butanedione, } \\
\text { 3-hydroxy-4-phenyl-2-butanone, } \\
\text { 3-hydroxy-1-phenyl-2-butanone, } \\
\text { 3-hydroxy-4-phenyl-3-buten-2-one }\end{array}$ & Greece & [47] \\
\hline Thymus capitatus & Pentanoic acid, phenylacetonitrile & Greece & [77] \\
\hline $\begin{array}{l}\text { Algaroba (Prosopis } \\
\text { juliflora (Sw.) DC) }\end{array}$ & Rose oxide & Brazil & {$[71]$} \\
\hline $\begin{array}{l}\text { Angico (Anadenanthera } \\
\text { colubrina) }\end{array}$ & Benzenethanol & Brazil & [71] \\
\hline Caraway & Benzaldehyde & Lithuania & [12] \\
\hline $\begin{array}{l}\text { Chanana (Turnera } \\
\text { ulmifolia L.) }\end{array}$ & D-Sylvestrene & Brazil & [71] \\
\hline $\begin{array}{l}\text { Christ's thorn (Paliurus } \\
\text { spina-christi) }\end{array}$ & $\begin{array}{l}\text { Nonanal, lilac aldehyde (isomers I-IV), decana, } \\
\text { methyl nonanoate, hexanoic acid, 2-ethylhexanoic } \\
\text { acid }\end{array}$ & Croatia & \\
\hline Cloudberry & 1-Propanol, $p$-cymene, isophorone, citral & Finland & [13] \\
\hline Honey-dew & 2,3-Butanethiol, acetic acids isomers & Poland & [37] \\
\hline $\begin{array}{l}\text { Juazeiro (Ziziphus } \\
\text { juazeiro Mart) }\end{array}$ & $\begin{array}{l}\text { Aromatic aldehydes, benzaldehyde, } \\
\text { benzeneacetaldehyde }\end{array}$ & Brazil & [21] \\
\hline $\begin{array}{l}\text { Jurema branca (Mimosa } \\
\text { arenosa willd Poir) }\end{array}$ & $\begin{array}{l}\text { Sulfur compounds, ketones, hexanol, limonene, } \\
\alpha \text {-farnesene, } \delta \text {-cardinene }\end{array}$ & Brazil & [21] \\
\hline Lacy phacelia & Hexan-1-ol, lavender lactone & Poland & [4] \\
\hline Lingonberry & $\begin{array}{l}\text { Vanillin, 3-hydroxy-4,5-dimethyl-2(5H)-furanone, } \\
\text { ethyl 3-phenylpropanoate }\end{array}$ & Finland & [13] \\
\hline $\begin{array}{l}\text { Malicia (Mimosa } \\
\text { quadrivalvis L.) }\end{array}$ & Linalool & Brazil & {$[71]$} \\
\hline Sweetclover & Phenylc acetic acid, (Z)-3-nonenal & Finland & [13] \\
\hline Thistle & $\begin{array}{c}\text { Nonanal, furfural, decanal, 3,6-dimethyl- } \\
\text { 2,3,3a,4,5,7a-hexahydrobenzofuran, } \\
\text { benzaldehyde, } \alpha \text {-linalool, lilac aldehyde (isomer } \\
\text { IV), hotrienol, phenylacetaldehyde, } \\
\text { 4-oxoisophorone, benzyl alcohol, 2-phenylethanol, } \\
\text { octanoic acid, nonanoic acid, methyl anthranilate }\end{array}$ & Italy & [17] \\
\hline Thymelaea hirsuta & $\begin{array}{l}\text { Benzene propanol, benzylalcohol, hexanol, } \\
\text { 4-methoxyphenol }\end{array}$ & Palestine & [86] \\
\hline Tolpis virgata & 3,5-Dihydroxytoluene, tridecane & Palestine & [86] \\
\hline Ulmo & $\begin{array}{c}\text { Benzaldehyde, octane, nonanal, } \\
\text { 4-methoxybenzaldehyde, isophorone, } \\
\beta \text {-damascenone, lyrame, 4-vinylanisole }\end{array}$ & Chile & {$[14]$} \\
\hline $\begin{array}{l}\text { Velame branco (Croton } \\
\text { heliotropiifolius Kunth) }\end{array}$ & Volatile acids & Brazil & [21] \\
\hline
\end{tabular}




\subsection{Geographical Characterization of Honey by SPME-GC-MS}

As mentioned before, volatile profile of honey has been proposed as marker also for geographical authentication.

Cioltaus at al. [8] successfully distinguished multifloral honeys from different areas of Transylvania, using SPME-GC-MS technique. The differentiation of volatile profile was obtained between varieties of different native floral sources (mountain, hill, valley, urban). $D$-limonene, isopulegol, 1-octen-3-ol, 1-octen-3-one, lilac aldehyde B, $\beta$-elemene, and transcalamenene were identified as honey markers for the valley source. Similarly, dimethyl sulphide, 3-hydroxy-butanal, isodihydro lavandulyl aldehyde, octanoic acid, myrtenol, and 2,4-di-tert-bytylphenol were identified as markers for hill honey. Especially, for mountain honey, the markers were $4 H$-pyran-4-one-2,3-dihydro-3,5-dihydro-3,5-dihydroxy-6-methyl, 5-hydroxy-methyl-furfural, and 2,2,4-trimethyl-1,3-pentanediol diisobutyrate, and for urban honey, the markers were 4H-pyran-4-one-2,3-dihydro-3,5-dihydro-3,5-dihydroxy-6methyl, 5-hydroxy-methyl-furfural, 2,2,4-trimethyl-1, and 3-pentanediol diisobutyrate.

Several studies of honey volatile composition that used SPME-GC-MS with chemometrics suggested that their combined usage in order to determine geographical origin of honey is a robust and reliable method of a high predictive ratio.

Ten chemical subclasses (sulphur compounds, ketones, aldehydes, alcohols, esters, nitrate compounds, aliphatic hydrocarbons, ethers, carboxylic and aromatic acids) of volatile compounds were identified for acacia honey samples from different geographical zones of Romania. In particular, the dominant compounds of acacia honey samples were 3-methyl-3-buten-1-ol for Transylvania region, ethanol, acetic acid, 5-ethenyldihydro-5furanone for the southern part of Romania, acetone, 3-methyl-3-buten-1-ol, trans-linalool oxide, and benzemethanol for the eastern part of Romania. Applying statistical analysis, it was suggested that multiple volatiles are more suitable for discrimination of acacia honey based on geographical origin [2].

Another HS-SPME-GC-MS-based profiling for discrimination of citrus and thyme honey from different geographical origins of Greece was used by Aliferis and co-workers [47]. This variable classification was revealed by applying chemometric models, OPLS-DA, and OPLS-HCA, providing good discriminative ability. This discrimination was achieved using the most influencing fragments $(\mathrm{m} / \mathrm{z})$, without the identification of each compound.

Volatile compounds of Sudanese honeys were determined and included aldehydes, alcohols, carboxylic acids, ketones, esters, hydrocarbons, norisoprenoids, phenols terpenes, and derivatives. PCA was used and showed clear classification of the tested unifloral honeys with the same floral source from different geographical origin [78].

Determination of volatile profile of citrus honeys from different Mediterranean countries (Greece, Spain, Egypt, and Morocco) was performed using HS-SPME-GC-MS. LDA analysis of geographical sources of citrus honeys correctly classified these samples from different Mediterranean countries (Figure 2) [48]. Applying the above combination of techniques on Greek Thymus capitatus (L.) [61] and Greek pine [62] honey revealed that selected volatile compounds can clearly distinguish the geographical origin of these honeys. Performing MANOVA at the thyme honey samples, the volatile compounds of formic acid ethyl ester, formic acid, acetic acid, 1-hydroxy-2-propanone, octane, terpinen-4-ol, decanal, decanoic acid ethyl ester, and 4,7,7-Trimethyl-bicyclo (3,3,0)-octan-2-one were defined as markers for the determination of their geographical origin. In the case of pine honey samples as chemical markers of geographical origin, the following compounds were identified: hexanoic acid ethyl ester, 2,3-butanediol, decane, $\beta$-thujone, heptanoic acid ethyl ester, 1-methyl-4-(1-methylethenyl), benzene, nonanal, and 2-ethyl-1-hexanol. 

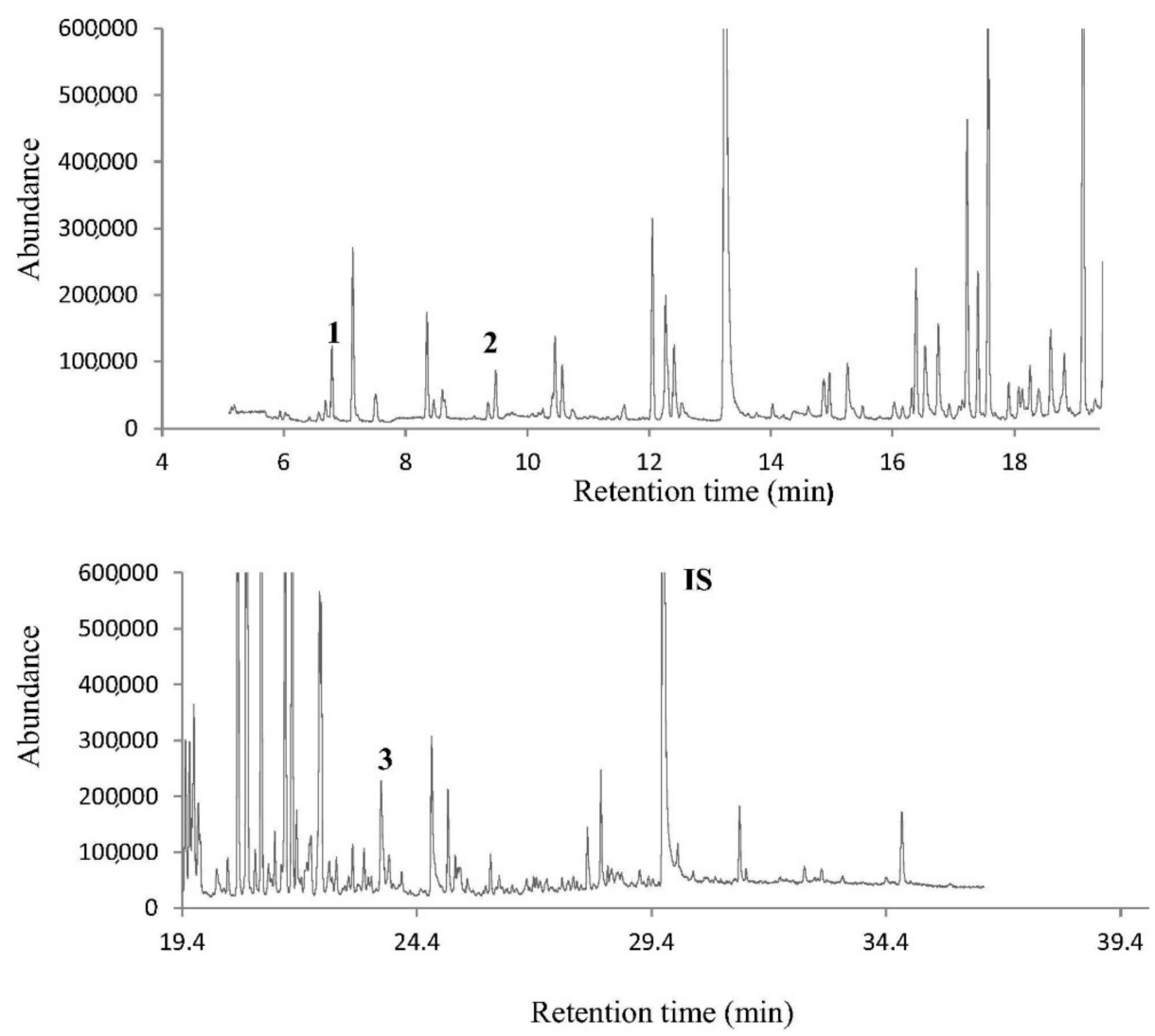

Figure 2. A typical gas chromatogram of citrus honey from Egypt. Possible volatile markers of geographical origin are indicated in bold. 1: heptane, 2: 2-methyl-butanal, 3: methyl anthranilate. IS: internal standard. Reprinted with permission from ref. [48]. Copyright 2016 Copyright Elsevier Ltd.

Regarding the aforementioned studies, SPME-GC-MS fingerprinting has been proven to be a powerful method for the discrimination and classification of honey. Volatile markers of honey that determine its botanical and geographical origin include different classes of compounds, including monoterpenes, norisoprenoids, sesquiterpenes, benzenoids, alcohols, esters, ketones, and aldehydes, that have been proposed using also chemometric analyses potentiated the effectiveness of the above method. The assessment of botanical and geographical origin of honeys is based on the relative abundance of volatile compounds since their nature and relative amount represent a distinctive fingerprint.

The main source of volatile compounds of honey is the nectar of the flower, thus the monofloral honeys have a characteristic pattern of volatiles composition, and only these specific volatile compounds could be used for floral origin differentiation. However, these biomarkers are not always the same since differences-even within a single type of monofloral honey due to the plant variety, the geographical origin or local beekeeping practices-are often observed.

As mentioned above, a standard volatile profile of honeys is not possible since the chemical composition of honey is season-dependent and strongly affected by its geographic origin. Honey produced in different regions, areas, cities, and countries possesses a characteristic profile due to the climatic conditions. Moreover, the resulted volatile profile of honey is heavily dependent on the conditions of isolation and detection techniques. For example, regarding SPME, when the extraction is performed at higher temperatures, the conditions become favorable for the extraction of compounds with low volatility, and vice versa. 


\section{Authentication of Honey Using IR Spectroscopy}

Infrared spectroscopy is considered an ideal technique for qualitative and quantitative determination of organic compounds. Specific absorption bands generated by characteristic groups of the compounds presented at a sample allow quality control of honey. The use of IR is widely accepted since it is low-cost, not sample-destructive, and easy to use. Moreover, analysis of the vast data obtained with chemometrics provide reliable results.

\subsection{Detection of Honey Adulteration Using IR Spectroscopy}

Infrared-based spectroscopy can be used for the detection of different adulterants in honey at different ranges of absorption. Chemometrics has been used as an essential tool for chemical fingerprinting of honey (Table 2).

Chen et al. [91] used near-infrared (NIR) spectroscopy on blossom honey to determine adulteration with high fructose corn syrups. The characteristic bands of blossom honey spectrum were around $6851 \mathrm{~cm}^{-1}\left(\mathrm{O}-\mathrm{H}\right.$ stretch), $5607 \mathrm{~cm}^{-1}\left(\mathrm{CH}_{2}\right.$ group), $5201 \mathrm{~cm}^{-1}$ (O-H stretch and bend band), $4782 \mathrm{~cm}^{-1}$ (O-H deformation band and $\mathrm{C}-\mathrm{O}$ stretch band), $4686 \mathrm{~cm}^{-1}$ (C-H stretch and deformation band), and $4182 \mathrm{~cm}^{-1}\left(\mathrm{CH}_{2}\right.$ stretch and deformation band). By using discriminant partial least squares analysis at different spectral ranges, it was shown that the adulterated honey could be better distinguished from unadulterated honey, with a correct classification rate of $92.13 \%$, between $6000-10,000 \mathrm{~cm}^{-1}$. For the determination of high fructose corn syrup in honey, Ferreiro-González et al. [55] applied visible (Vis)-NIR spectroscopy. According to their results, HCA and PCA did not achieve full differentiation of the samples; however, honey samples were fully distinguished by using supervised LDA. The coefficients of the wavelengths 444.5 and $1462 \mathrm{~nm}$ are high and negative at low ratios of adulteration whereas at higher ratios of adulteration, they become positive. At $472.5 \mathrm{~nm}$, the increase in adulteration leads to an increased negative coefficient. In another study, Fourier transform infrared (FTIR) spectroscopy was used to quantify corn syrup in honey to detect the adulteration based on sugar content. The differentiation between pure and adulterated honeys was obtained clearly at the spectral range of $1150-650 \mathrm{~cm}^{-1}$, which was characteristic of pure honeys [92]. Moreover, in a study by Li et al. [57], mid-infrared (MIR) spectroscopy combined with chemometrics (PLS) successfully quantified high fructose syrup (HFGS) in honey samples. The absorption maxima of pure honey and HFGS were achieved at 3285, 2930, 1642, 1370-1420, 1200-1350, and $1025 \mathrm{~cm}^{-1}$. The characteristic band at $3285 \mathrm{~cm}^{-1}(\mathrm{OH}-$ stretching vibrations of water) raises by increasing HFGS concentration due to its high moisture. The authors fused the data provided by MIR and Raman spectroscopy at low-level, mid-level, and high-level to investigate the best model in terms of prediction accuracy of the detection of adulteration. After data fusion combined with chemometrics, the best prediction ability and stronger stability was revealed by the high-level model, compelling it ideal for quantitative analysis.

NIR spectroscopy combined with the competitive adaptive reweighted sampling (CARS)-PLS-LDA model seem to be effective to classify honeys in both cases of adulteration, with high fructose corn and maltose syrup. The characteristic peaks of absorbance were the same for pure and adulterated honeys: $6891,5619,5155,4778,4395$, and $4231 \mathrm{~cm}^{-1}$. For the CARS-PLS-LDA analysis, the chosen variables were located in the ranges of $10,000-7300 \mathrm{~cm}^{-1}, 6800-5500 \mathrm{~cm}^{-1}, 4800-4200 \mathrm{~cm}^{-1}$ and $9800-8200 \mathrm{~cm}^{-1}, 5620-5500 \mathrm{~cm}^{-1}$, and $4200-4100 \mathrm{~cm}^{-1}$ for each model. The spectral data were further statistically processed by using PLS regression and showed that the quantification was sufficiently obtained for maltose syrup-adulterated honey samples from same and different floral origins but was not obtained for high fructose corn syrup-adulterated honeys [93]. The same spectroscopic technique (NIR), using three different NIR instruments (a laboratory, as well as a portable and a mobile instruments), and statistical techniques (PLSDA), was applied to South African honeys. Particularly good classification accuracies were obtained between the non-adulterated and adulterated honeys and verified the capability of NIR spectroscopy to detect the addition of sugars and cheap imported honey, irrespective of the type of instrument. Specifically, the PLS-DA model built 
on the data collected from the laboratory instrument shows that a significant contribution to the model is given by the intervals $1000.0-1038.6 \mathrm{~nm}, 1097.5-1132.8 \mathrm{~nm}, 1167.1-$ $1199.6 \mathrm{~nm}, 1274.2-1283.4 \mathrm{~nm}, 1328.4-1355.0 \mathrm{~nm}$, and 1375.9-1386.6 nm. In the case of the PLS-DA model from the portable instrument, the meaningful spectral intervals were 908.1-976.2 nm, 1143.5-1162.1 nm, 1205.4-1267.4 nm, and 1447.0-1453.2 nm. The last PLSDA model from the mobile instrument indicated that the spectral regions which contribute most significantly to the discrimination among the categories are $861.8-888.8 \mathrm{~nm}$, 955.9-989.3 nm, 1356.7-1363.1 nm, $1504.9-1530.6 \mathrm{~nm}, 1594.7-1754.4 \mathrm{~nm}, 1786.3-1856.5 \mathrm{~nm}$, 2003.5-2035.4 nm, 2131.6-2196.0 nm, 2234.6-2273.4 nm, and 2423.0-2514.8 nm [65]. NIR spectroscopy combined with aquaphotomics were used to detect adulterants (corn, sucrose, high fructose, beet, and rice syrups) in Manuka honey. PCA and PLSR model regression vector analyses were performed at the spectral region of 1300-1800 nm, and 12 characteristic bands (1324, 1344, 1356, 1386, 1418, 1426, 1434, 1460, 1476, 1502, 1528, and $1586 \mathrm{~nm})$ were selected according to the results of analysis, providing classification of non- and syrup-adulterated Manuka honeys [94].

Aliaño-González et al. [50] used Vis-NIR spectroscopy combined with chemometrics (HCA, LDA, PLS) in order to guarantee the quality of multi-floral Granada Protected Designation of Origin (PDO) honey by determining common adulterants (rice and fructose syrups, invert and brown cane sugars). Thirteen significant wavelengths (465.5 nm, $499.0 \mathrm{~nm}, 559.5 \mathrm{~nm}, 675.5 \mathrm{~nm}, 736.0 \mathrm{~nm}, 1104.5 \mathrm{~nm}, 1170.5 \mathrm{~nm}, 1253.0 \mathrm{~nm}, 1324.5 \mathrm{~nm}$, $1423.5 \mathrm{~nm}, 1467.5 \mathrm{~nm}, 1544.5 \mathrm{~nm}$, and $1958.0 \mathrm{~nm}$ ) were selected for the discrimination using Fisher's linear discriminant functions. Most of the bands are characteristic regions (550-600 nm, $1190 \mathrm{~nm}$, and 1700-1900 nm) of the Vis-NIR spectra (Figure 3). The combination of these techniques clearly distinguished non-adulterated from adulterated honeys, by developing an adulteration model which included all the adulterants used as well as a model for each adulterant.

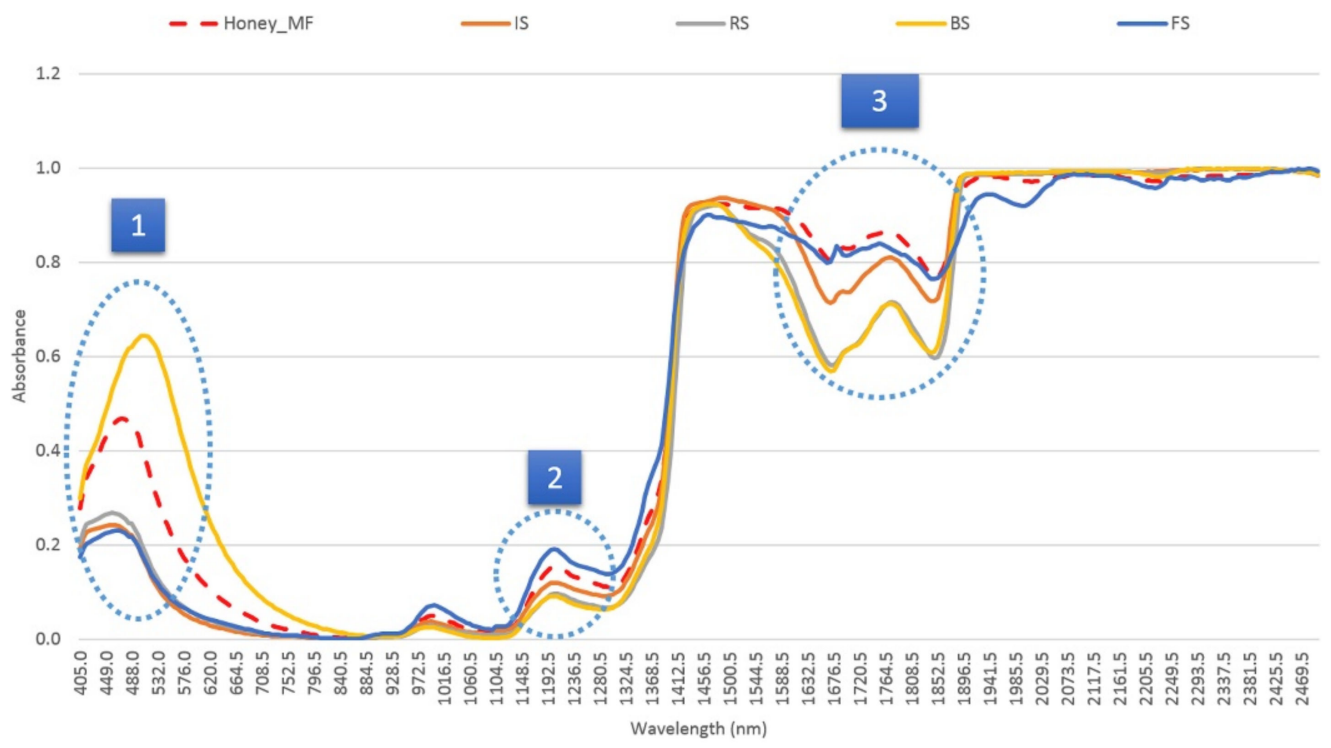

Figure 3. Average Vis-NIR spectra for pure multi-floral honey and for the four different sweeteners used for the adulteration (rice syrup (RS), invert sugar (IS), brown cane sugar (BS) and fructose syrup (FS)), in the regions 1, 2 and 3 the honey samples show different intensities depending on the type of adulterant. Reprinted with permission from ref. [50]. Copyright 2019 Copyright Elsevier B.V.

In another study, FT-MIR technique was employed to support electrical impedance spectroscopy (EIS) analysis to characterize and quantify sugar adulterated honeys from different varieties. However, FT-MIR technique used alone successfully differentiated non-adulterated and adulterated honeys. Specifically, the addition of sucrose syrup was detected by the increase in absorbance in the region of $1800-650 \mathrm{~cm}^{-1}$ and the Full-Width- 
at-Half-Maximum (FWHM) was found at $1056 \mathrm{~cm}^{-1}$ for all honey samples, related to $\mathrm{C}-\mathrm{O}, \mathrm{C}-\mathrm{C}$, and $\mathrm{O}-\mathrm{H}$ stretching, and was increased by increasing the concentration of the adulterant [95]. FT-MIR analysis was also carried out for pure and adulterated Trigona spp. and Apis spp. honey by Mail et al. [96]. The characteristic peaks of Trigona spp. and Apis spp. honey were 3272, 2934, 1643, 1416, 1345, 1256, and $1026 \mathrm{~cm}^{-1}$. In the case of Apis honey, the characteristic spectra were changed in all the regions with the addition of vinegar, even at low percentage due to the dilution by the amounts of water in the vinegar. The adulterated Trigona spp. honeys with water also shift away from pure honey at most of the spectral regions. Thus, the spectroscopic data showed that this technique could rapidly detect the adulterants in both honey types.

Attenuated total reflectance (ATR)-FTIR spectroscopy coupled with chemometrics was used in a study on stingless bee (Heterotrigona itama) honey from Malaysia for its capacity to detect adulteration by five adulterants including fructose, glucose, sucrose, corn syrup, and cane sugar. Applying PCA, all the adulterants were discriminated at the spectral region $1180-750 \mathrm{~cm}^{-1}$. Especially, the absorption peaks at 1054,876 , and $779 \mathrm{~cm}^{-1}$ were attributed to the increasing percentages of fructose. The characteristic peaks at 1022, 991, and $898 \mathrm{~cm}^{-1}$ were assigned to the presence of glucose, and at 991 and $921 \mathrm{~cm}^{-1}$ to the presence of sucrose. PLSR analysis was also able to quantity honey adulteration in all five cases [97]. In another study of honey adulteration with sugar, FTIR spectrometer with an ATR device was applied to honeys produced in different places of Ecuador combined with PCA. This combination showed to be ideal for the quality control of honey [59]. The ATR-FTIR technique has been also used alongside chemometrics for the estimation of the adulteration with commercial sugars of aren (Arenga pinnata), coconut, and cane sugar of Indonesian honeys. PCA and PLS analyses were applied for differentiation and quantification of the samples, respectively. It was proved that this combination is suitable for the detection of adulteration and measurement of the added sugar at Indonesian honeys [98].

Pure (105 samples) and adulterant (154 samples) honeys were analyzed by NIR and MIR spectroscopies combined with chemometrics to detect adulteration by rice and corn syrups. Principal components analysis (PCA) and PLS-DA models were used for adulterant determination. PCA was not able to distinguish adulterated honeys. However, clear discrimination of honey adulteration by spectrum data was shown by pretreatment of second derivative and by PLS-DA [80]. In another study, natural and syrup-adulterated honeys from China were analyzed using both spectroscopies, NIR and ATR-FTIR. Two types of adulterants were studied: type 1, rice and beet syrup, and type 2, high fructose corn, corn, maltose, and sucrose syrup. Between NIR and ATR-FTIR, more characteristic peaks were observed in the second technique. The spectral region at $750-1500 \mathrm{~cm}^{-1}$ was related to the absorption of major monosaccharides (such as fructose and glucose) and disaccharides (such as sucrose) and the region at $750-900 \mathrm{~cm}^{-1}$ was attributed to anomalous peaks corresponding to the characteristic absorptions of sugars. The integrated spectral data of honeys were subjected to Support Vector Machine (SVM) to detect adulteration. Data fusion and parameter optimization algorithms helped to create the best SVM model characterized by accuracy, sensitivity, and specificity in adulteration with syrup [51].

Table 2. Application of vibrational spectroscopic techniques coupled with chemometrics in detection of honey adulteration.

\begin{tabular}{cccc}
\hline Type of Spectroscopy & Chemometrics Methods & Type of Adulterants & References \\
\hline ATR-FTIR & PCA, SIMCA, PLS & $\begin{array}{c}\text { Fructose syrup, glucose syrup, } \\
\text { sucrose syrup, corn syrup, cane sugar }\end{array}$ & [97] \\
ATR-FTIR & PCA, DA, PLS & $\begin{array}{c}\text { Commercial sugars of aren (Arenga } \\
\text { pinnata), coconut, cane sugar }\end{array}$ & [98] \\
\hline ATR-FTIR and Raman & PCA & Sucrose, reducing sugars & [59] \\
\hline MIR and Raman & PLS, Data fusion & High fructose corn syrup, maltose & syrup \\
\hline
\end{tabular}


Table 2. Cont.

\begin{tabular}{|c|c|c|c|}
\hline Type of Spectroscopy & Chemometrics Methods & Type of Adulterants & References \\
\hline NIR & DPLS & High fructose corn syrup & [91] \\
\hline NIR & CARS, PLS- LDA & High fructose corn syrup & [93] \\
\hline NIR & PLS-DA & $\begin{array}{l}\text { Glucose syrup, fructose syrup, cheap } \\
\text { imported honey }\end{array}$ & {$[65]$} \\
\hline NIR & PCA, PLS & $\begin{array}{l}\text { Corn syrup, sucrose syrup, high } \\
\text { fructose corn syrup, beet syrup, rice } \\
\text { syrup }\end{array}$ & [94] \\
\hline NIR and MIR & PCA, PLS, DA & Rice syrup, corn syrup & [80] \\
\hline NIR and ATR-FIIR & SVM, Data fusion & $\begin{array}{l}\text { Type 1: rice and beet syrup, type } 2 \text { : } \\
\text { high fructose corn syrup, corn syrup, } \\
\text { maltose syrup, sucrose syrup }\end{array}$ & [51] \\
\hline Raman & $\begin{array}{l}\text { PCA, PLS, artificial neural } \\
\text { network ANN }\end{array}$ & Glucose, fructose, sucrose, maltose & [58] \\
\hline Raman & $\begin{array}{l}\text { Adaptive iteratively } \\
\text { reweighted penalized least } \\
\text { squares airPLS, PLS, DA }\end{array}$ & $\begin{array}{l}\text { High fructose corn syrup, maltose } \\
\text { syrup }\end{array}$ & {$[64]$} \\
\hline Raman & SIMCA & $\begin{array}{c}\text { Molasses, date molasses, grape } \\
\text { molasses, high fructose corn syrup, } \\
\text { corn syrup (dark and light), sucrose, } \\
\text { inverted sugar }\end{array}$ & [63] \\
\hline NIR & HCA, PCA, LDA, PLS & High fructose corn syrup & {$[55]$} \\
\hline NIR & HCA, LDA, PLS & $\begin{array}{l}\text { Inverted sugar, rice syrup, brown } \\
\text { cane sugar, fructose syrup }\end{array}$ & {$[50]$} \\
\hline
\end{tabular}

\subsection{Determination of Honey Origin Using IR Spectroscopy}

The combination of IR with chemometrics provide satisfactory discrimination and rapid first-line classification of honey based on the botanical and geographical origin.

A study by Mail et al. [96] suggested that Trigona spp. honey can be clearly distinguished from Apis spp. honey using FTIR technique, based on the differentiation of their absorbance at the identified functional group regions. Both honeys presented almost the same spectra, but Trigona spp. honey exhibited lower absorption at the region of carbohydrates $\left(3280-3271 \mathrm{~cm}^{-1}, 2935-2931 \mathrm{~cm}^{-1}, 1416-1252 \mathrm{~cm}^{-1}, 1031-1020 \mathrm{~cm}^{-1}\right)$ and higher absorption at region of water $\left(1643-1642 \mathrm{~cm}^{-1}\right)$ in comparison with Apis spp. honey (Figure 4). Similarly, the botanical source of 30 honey types of eight different varieties (eucalyptus, litchi, neem, lemon, ginger, Kasmiri white, BR Hills, and Pan India) was also evaluated by ATR-FTIR spectroscopy and chemometrics. PCA was employed and successfully classified the honey samples, based on the spectral differences in the region of $1800-750 \mathrm{~cm}^{-1}$. Through the comparative overlay of ATR-FTIR spectra of the different honeys in this region, the characteristic peaks were 1636, 1454,1431, 1366, 1261, 1151, 1104, $1079,1057,1034,967,926$, and $887 \mathrm{~cm}^{-1}$ [9]. Seventy Italian honey samples from seven different botanical sources (acacia, orange, chestnut, eucalyptus, lavender, honeydew, and linden) were analyzed using FT-NIR spectroscopy. The spectroscopic data were further evaluated by PLS-DA and by sequential and orthogonalized covariance selection (SOCovSel)-LDA. According to Variable Importance in Projection (VIP), NIR spectroscopy did not achieve particularly good classification between the seven different varieties of honey samples. However, the mid-level data approach performed a more accurate prediction of the honey samples belonging to the alternative class "Others", providing fewer false positives than the other strategies and improvement in the overall classification rates [99]. 


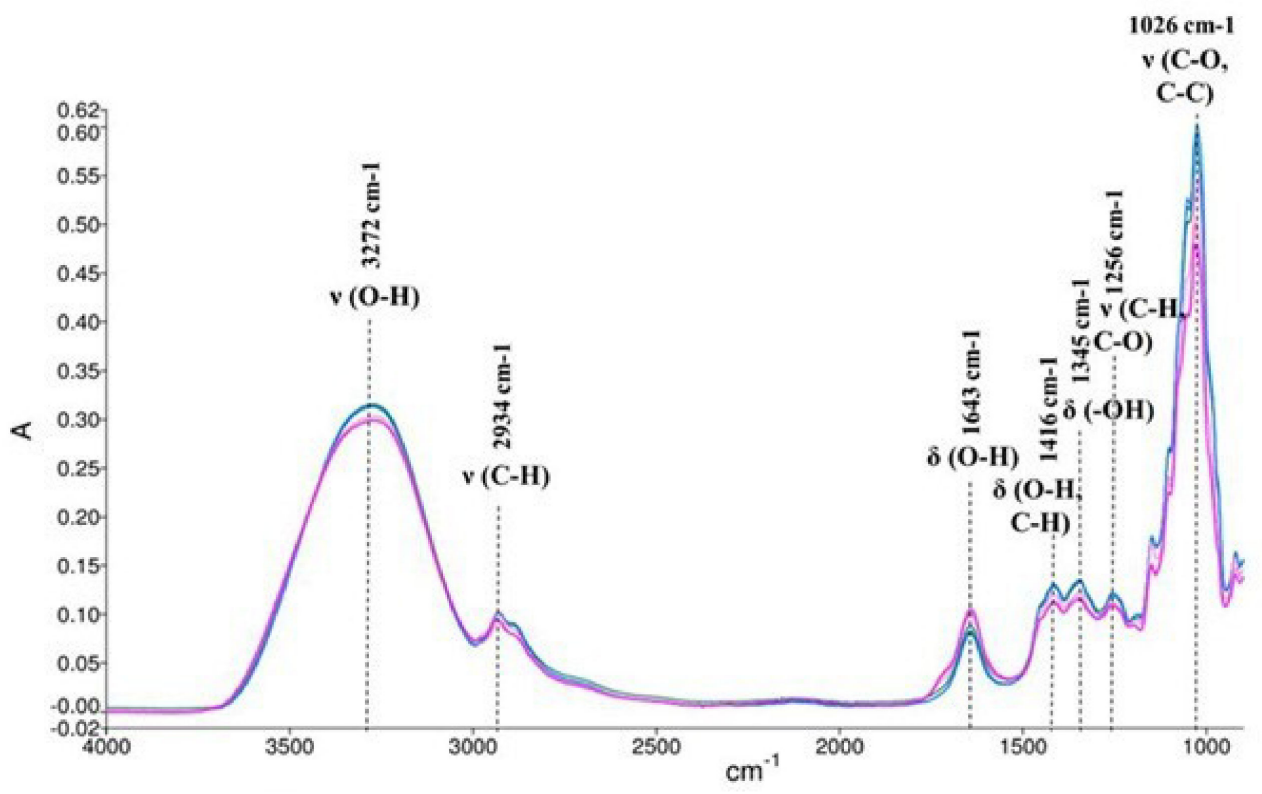

Figure 4. FTIR spectra curve and identified functional group region for Trigona honey (pink) and Apis honey (blue), x-axis: wavelength and y-axis: Absorbance. Reprinted with permission from ref. [96]. Copyright 2019 Copyright Oriental Scientific Publishing Company.

Near-infrared spectrum and mid-infrared spectrum of three different raw honey sources (vitex, jujube, and acacia) have been collected to evaluate their botanical origin. According to spectral data and by using different types of chemometric analysis models, PLS-DA, SVM, and interval partial least squares (iPLS), a rapid and accurate classification of honeys based on their botanical origin was achieved. By using the iPLS model, it was revealed that the optimized spectral regions for botanical discrimination of NIR were $6310-5847 \mathrm{~cm}^{-1}$ and of MIR were $3397-3298 \mathrm{~cm}^{-1}, 2893-2592 \mathrm{~cm}^{-1}$, and $1381-980 \mathrm{~cm}^{-1}$ [80].

The combination of IR spectroscopy with other techniques was also reported for botanical characterization in some studies.

For botanical characterization of eight different varieties of Italian honeys, five different analytical techniques (IR, NIR and Raman spectroscopy, Proton Transfer Reaction-Mass Spectrometry (PTR-MS), and electronic noise) and fused data by PLS-DA were used. The analysis of the regression coefficients showed the effectiveness of NIR spectroscopy to discriminate almost all the investigated classes. Specifically, the band at $4000-4180 \mathrm{~cm}^{-1}$ was characteristic for chestnut, sunflower, and multiflower honeys, while the band at $4180-4230 \mathrm{~cm}^{-1}$ was observed at citrus, linden, chestnut, and rhododendron samples. Sunflower, multiflower, and chestnut honeys were differentiated by other honey samples at $4232-4296 \mathrm{~cm}^{-1}$. Discrimination of citrus, linden, and chestnut from honeydew, robinia, and sunflower was performed at $4296-4388 \mathrm{~cm}^{-1}$; for citrus, linden, rhododendron from robinia, multiflower, honeydew, and chestnut, discrimination was performed at the band $4388-4590 \mathrm{~cm}^{-1}$. Moreover, the combination of Raman and NIR spectroscopy and PTR-MS provided the best results of honey samples discrimination based on botanical origin, as verified by PLS-DA and high-level data fusion method [16]. Different physicochemical techniques such as elemental profiling, stable isotope analysis, metabolomics, quadrupole time of flight mass spectrometry (UPLC-QToF MS), and NIR, FT-IR, and Raman spectroscopic fingerprinting were used for botanical discrimination of four different honeys (rata, kamahi, clover, and manuka) from New Zealand by using also multivariate statistical analysis. OPLS-DA was applied to evaluate the best technique for classification or to prove whether their combination provides more accurate results. The best discrimination of honeys was achieved by metabolomic and element/isotopic data. In the case of spectroscopic 
techniques (NIR, FT-IR, and Raman), the best results were obtained in combination with the other techniques for floral classification of honeys [56].

For geographical discrimination in a study by Guelpa et al. [65], near-infrared spectroscopy coupled with statistical analysis was performed to identify authenticity of South African honey. By applying PLS-DA on the spectrum data, honeys were successfully classified based on the geographical origin-South African honeys were differentiated from non-South African honeys. The characteristic bands concerning the geographical classification were shown at the above paragraph 3.1, related also with the determination of adulteration. Differentiation of wild honeys from different areas of Indonesia was achieved using ATR-FTIR technique coupled with multivariate statistical analysis. The spectroscopic data were subjected to DA for discrimination of honeys. The best discrimination model was obtained at the wavenumbers of 327, 1110, and $2933 \mathrm{~cm}^{-1}$ [98].

As far as the NIR region is concerned, the spectral curves and the absorbance peaks were similar for pure and adulterated honey. The characteristic peaks are $6851,5618,5157$, 4762,4394 , and $4103 \mathrm{~cm}^{-1}$. The absorption peak at $6851 \mathrm{~cm}^{-1}$ corresponds to first overtone of the $\mathrm{O}-\mathrm{H}$ stretch. The peak at $5618 \mathrm{~cm}^{-1}$ is the second harmonic of $\mathrm{C}=\mathrm{O}$ absorption, while the peak at $5157 \mathrm{~cm}^{-1}$ is assigned to the overtone of $\mathrm{O}-\mathrm{H}$ stretching and bending. The peak around $4762 \mathrm{~cm}^{-1}$ belongs to a combination of $\mathrm{O}-\mathrm{H}$ deformation band and $\mathrm{C}-\mathrm{O}$ stretch band. The peak at $4394 \mathrm{~cm}^{-1}$ is ascribable to the overtone of $\mathrm{C}-\mathrm{H}$ stretching and deformation and at $4103 \mathrm{~cm}^{-1}$ to the combination of $\mathrm{CH}_{2}$ stretch and deformation band. However, there are important peaks around 8403, 6839, 5168, 4773, 4386, and $4231 \mathrm{~cm}^{-1}$, where the samples show different intensities depending on the type of the adulterant (sucrose, fructose, and glucose).

In general, the MIR spectra of honey consist of six characteristic regions at specific wavenumbers, 3285, 2930, 1642, 1370-1420, 1200-1350, and $1025 \mathrm{~cm}^{-1}$. The absorption peak at 3285 and $1642 \mathrm{~cm}^{-1}$ are assigned to the $\mathrm{O}-\mathrm{H}$ stretching and bending vibrations of water, respectively. The absorption maxima at $2930 \mathrm{~cm}^{-1}$ corresponds to stretching vibrations of $\mathrm{O}-\mathrm{H}$ and the bands at $1370-1420 \mathrm{~cm}^{-1}$ correspond to deformation vibration of $\mathrm{C}-\mathrm{H}$ from cellulose and lipids. The peaks around $1200-1350 \mathrm{~cm}^{-1}$ are $\mathrm{N}-\mathrm{H}$ deformation and $\mathrm{C}-\mathrm{N}$ stretching vibrations. The absorption peak at $1025 \mathrm{~cm}^{-1}$ is assigned to $\mathrm{C}-\mathrm{O}$ and $\mathrm{C}-\mathrm{H}$ stretching vibrations. For the detection of adulteration, there are some absorption peaks at the region of $750-1500 \mathrm{~cm}^{-1}$ originating due to monosaccharides (such as fructose and glucose) and disaccharides (such as sucrose) in honey. In particular, the region $700-950 \mathrm{~cm}^{-1}$ is known as the "anomeric region of carbohydrates", contains anomalous peaks corresponding to the characteristic absorptions of sugars. In the case of adulteration of honey with high fructose syrup, the absorption peaks at $3285 \mathrm{~cm}^{-1}$ are increased due to the high moisture content. Moreover, major differentiation in the MIR spectra of adulterated honey is observed at $1054,867,822$, and $779 \mathrm{~cm}^{-1}$ by the presence of fructose, at 1022 , 991 , and $898 \mathrm{~cm}^{-1}$ by the presence of glucose and at 991 and $921 \mathrm{~cm}^{-1}$ by the presence of sucrose. Even though pure and adulterated honey provide similar spectra, the different absorption intensities at the characteristic peaks make it possible to use NIR and MIR for their identification.

It seems that the variation of honey associated with botanical and geographical origin using NIR and MIR spectroscopy is mainly based at $4000-8000 \mathrm{~cm}^{-1}$ and $800-4000 \mathrm{~cm}^{-1}$, respectively. In both cases, the optimized region of discrimination dependent on the chemometric model. Thus, depending on the discriminant model used, wavelengths corresponding to the vibrational transition of the main functional groups allow for sufficient variation.

\section{Authentication of Honey Using Raman Spectroscopy}

Raman spectroscopy is a suitable, efficient, fast, and inexpensive technique for quality control and evaluation of the chemical properties of honey. The main advantages of Raman spectroscopy are the small amount of sample required, the speed of analysis, the high reproducibility of data, and the avoidance of interference related to the water molecule. 
The verification of the origin and control of the authenticity of honey can be facilitated using chemometric approaches.

\subsection{Detection of Honey Adulteration Using Raman Spectroscopy}

Raman spectroscopy can be successfully used to detect adulteration of honey (Table 2).

Raman technique coupled with multivariate analysis was applied at honeys to identify and quantify sugars (glucose, fructose, maltose, and sucrose contents) and further to characterize them as adulterants. The characteristic spectral bands that correlated to sugars of honey were $314,341,415,530,617,744,776,790,838,856,911,933,1028$, and $1106 \mathrm{~cm}^{-1}$. PCA, partial least squares (PLS), and artificial neural network (ANN) were used to extract differentiation from the spectroscopic data which successfully led to the discrimination of sugar contents in honey [58]. Moreover, Raman technique was used by Salvador et al. [59] to detect the sugar content and the type of adulteration in commercial honeys of Ecuador. The main observed bands of honeys from Pichincha and Loja provinces were 326, 338, $419,516,630,707,817,862,918,1062$, and $1126 \mathrm{~cm}^{-1}$. These bands were assigned to the presence of sugar (glucose, fructose, and sucrose) at honey samples. The bands of pure honey at 817 and $862 \mathrm{~cm}^{-1}$, in the case of adulteration with sucrose, were overlapped with strong absorptions at 822 and $834 \mathrm{~cm}^{-1}$. Principal component analysis was applied and confirmed the applicability of Raman technique for the detection of adulteration of honey with glucose, fructose, and sucrose.

In another study, Raman spectroscopy was also used to detect adulteration of honey with high fructose corn syrup and/or maltose syrup. The characteristic bands corresponding to authentic and adulterated honeys were observed: $351,425,517,592,629,705,778$, $824,865,915,981,1065,1127,1264,1373$, and $1461 \mathrm{~cm}^{-1}$ (Figure 5). The spectra data were subjected to adaptive iteratively reweighted penalized least squares (airPLS). Using PLSLDA, classification of honeys was achieved in both cases of adulterants and in mixtures of them [64]. Chemometrics with Raman spectroscopy were successfully employed for the quantification of HFGCS (high fructose syrup) in adulterated honey, as well. At the band of $2791 \mathrm{~cm}^{-1}$, the absorption was increased by increasing the HFGS concentration, while at $1130 \mathrm{~cm}^{-1}$, the absorption was reduced due to the decrease in protein and amino acid content in the adulterated honeys. Three data fusion strategies were used and showed high predictability in the adulteration of honey, while the best results were obtained by the high-level data fusion process [57].

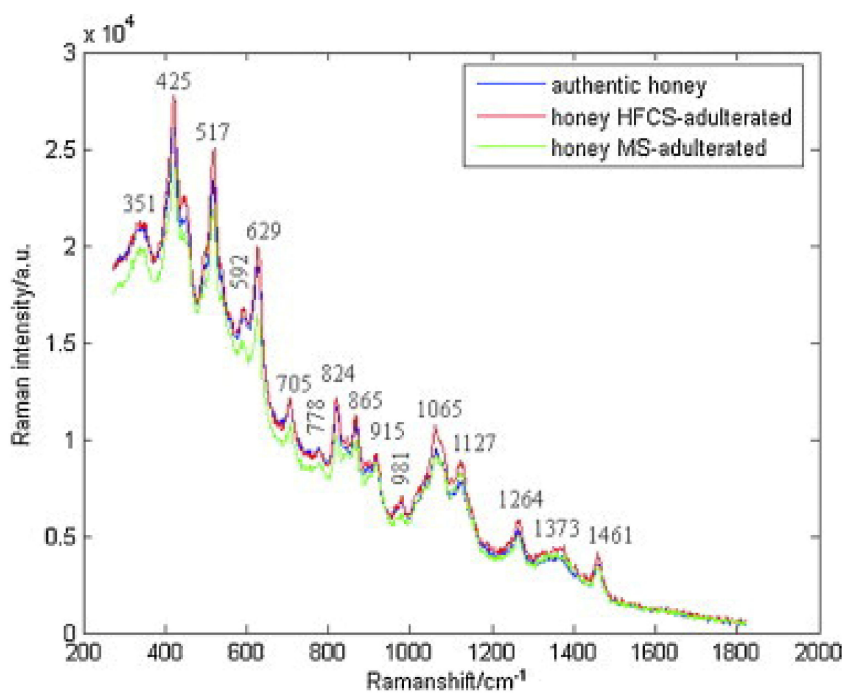

Figure 5. Raman spectra of a randomly selected authentic honey sample and the same honey sample adulterated with high fructose corn syrup $(40 \%, w / w)$ and maltose syrup $(40 \%, w / w)$. Reprinted with permission from ref. [64]. Copyright 2012 Copyright Elsevier Inc. 
Non-invasive techniques using a handheld and compact benchtop Raman system were employed to detect honey adulteration by molasses, date molasses, grape molasses, high fructose corn syrup, corn syrup (dark and light), sucrose, and inverted sugar. The characteristic spectroscopic bands found at 424, 517, 629, 706, 824, 1067, 1127, 1265, 1373, and $1461 \mathrm{~cm}^{-1}$ were concerning the presence of sugars. By performing SIMCA, classification of the pure and adulterated honeys with $100 \%$ specificity and sensitivity was achieved [63].

\subsection{Detection of Honey Origin Using Raman Spectroscopy}

Raman technique is capable of on-site testing of honey samples to authenticate and verify their label information based on its origin.

An analysis of one hundred Lavandula spp. honeys from different regions of Portugal was performed by FT-Raman spectroscopy combined with chemometrics (PLS) to determine their chemical composition. Lavandula spp. honey showed characteristic peaks at the region of 200-1500 $\mathrm{cm}^{-1}$. Specifically, the characteristic spectral peaks were found at $341,422,521,626,705,776,825,867,915,979,1072,1124,1266,1366$, and $1460 \mathrm{~cm}^{-1}$. The combination of the above techniques could be considered as a reliable tool for the quality prediction of Lavadula spp. honey (Figure 6) [54]. FT-Raman spectroscopy and statistical analysis were applied at commercial honeys to authenticate their labeling. According to the spectroscopic data generated $\left(424,517,629,706,824,1067,1127,1265,1373\right.$, and $\left.1461 \mathrm{~cm}^{-1}\right)$ and based on SIMCA analysis verification, the prediction of pure honey samples was rapidly and efficiently achieved [63].

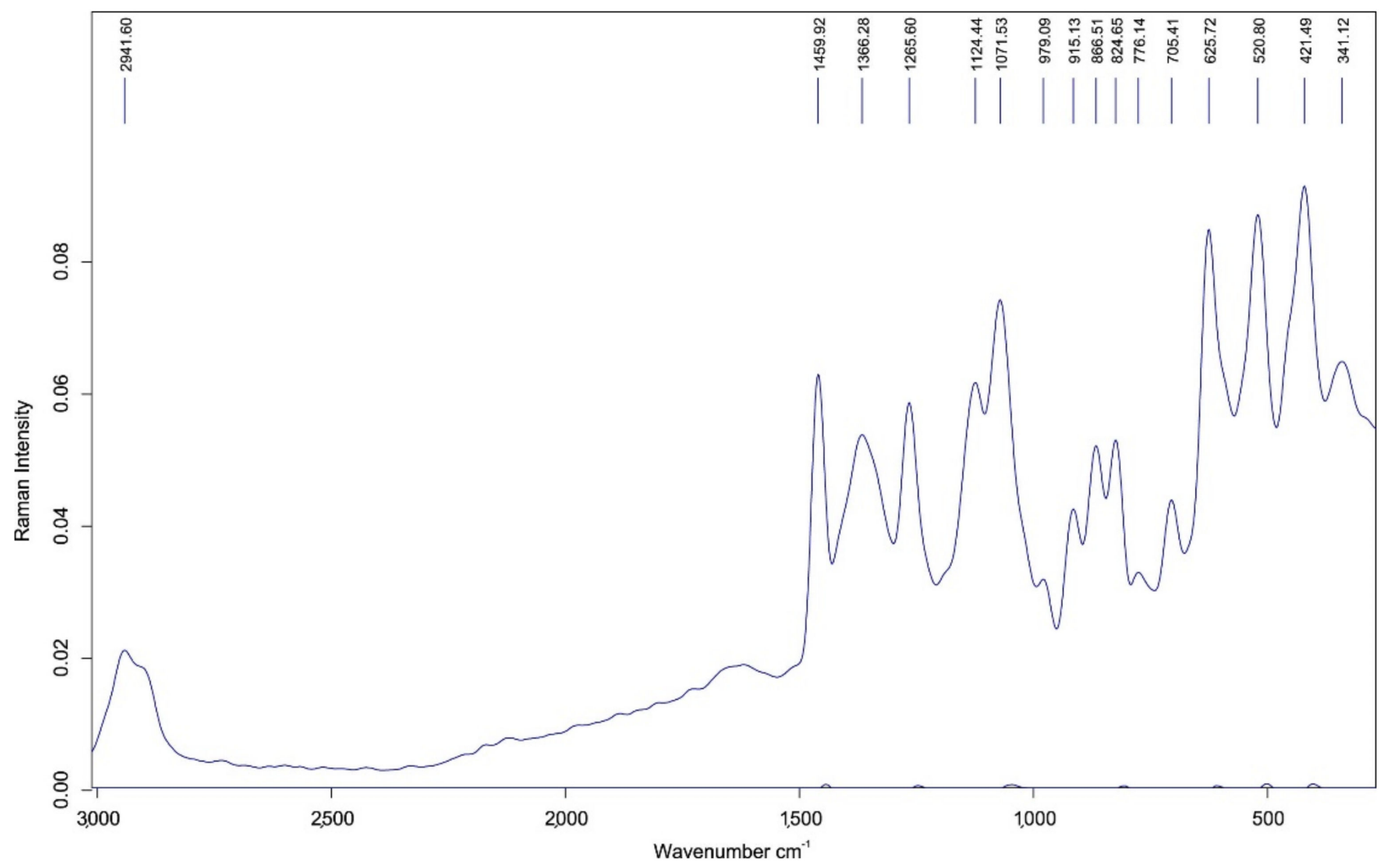

Figure 6. Average FT-Raman spectrum of the Lavandula spp. honey. Reprinted with permission from ref. [54]. Copyright 2017 Copyright Elsevier B.V.

Four pure honeys with different floral origins (clover, kamahi, manuka and rata) obtained from producers in New Zealand were discriminated using Raman spectroscopy. According to OPLS-DA, the optimum honey discrimination was achieved with the combination of NIR, FT-IR, and Raman techniques with elemental profiling, stable isotope 
analysis, and metabolomics [55]. In another study, Raman spectroscopy and other analytical techniques (IR and NIR spectroscopy, PTR-MS, and electronic noise) combined with multivariate data fusion methods were used for botanical discrimination of eight different varieties (citrus, chestnut, linden, sunflower, honeydew, multiflower, robinia, and rhododendron) of honey from Italy. Data analysis shows that chestnut and linden honeys were discriminated more effectively from the others, characterized by the largest positive or negative coefficient. In the case of chestnut honey, the region at $200-500 \mathrm{~cm}^{-1}$ and the band at $524 \mathrm{~cm}^{-1}$ allowed its discrimination from the other types. The discrimination of linden honey was achieved due to the bands at 1492, 1576, and $1666 \mathrm{~cm}^{-1}$ [16].

The Raman spectra of honey shows most of the spectral peaks in the region between $200-1500 \mathrm{~cm}^{-1}$, thus, the differentiation of authentic and non-authentic honey is obtained at this region. The characteristic bands generated from Raman spectra of honey, which were used to detect the presence of sugars as adulterants, were observed at 314, 341, 424, $517,629,706,824,871,918,979,1067,1127,1265,1373$, and $1461 \mathrm{~cm}^{-1}$. Moreover, at these spectral peaks the main differences for botanical and geographical discrimination were also revealed using chemometric analysis.

In particular, the region from $200-500 \mathrm{~cm}^{-1}$ is assigned to skeletal vibrational modes, namely $\mathrm{C}-\mathrm{C}-\mathrm{C}-, \mathrm{C}-\mathrm{C}-\mathrm{O}, \mathrm{C}-\mathrm{O}$, and $\mathrm{C}-\mathrm{C}$. The peaks 424 and $517 \mathrm{~cm}^{-1}$ correspond to deformations of $\mathrm{C}-\mathrm{C}-\mathrm{O}$ and $\mathrm{C}-\mathrm{C}-\mathrm{C}$, the peak at $629 \mathrm{~cm}^{-1}$ is assigned to ring deformations of fructose, while the peak at $706 \mathrm{~cm}^{-1}$ corresponds to the stretching of $\mathrm{C}-\mathrm{O}$ and bending vibrations of $\mathrm{C}-\mathrm{C}-\mathrm{O}$ and $\mathrm{O}-\mathrm{C}-\mathrm{O}$ of glucose. The spectral peak at $776 \mathrm{~cm}^{-1}$ was assigned to the $\mathrm{C}-\mathrm{C}$ stretching and $\mathrm{C}-\mathrm{H}$ vibrations present in glucose. The two peaks at 825 and $871 \mathrm{~cm}^{-1}$ are related to the vibration of $\mathrm{C}-\mathrm{H}$ and $\mathrm{CH}_{2}$ deformation and $\mathrm{C}-\mathrm{O}-\mathrm{H}$ bending of fructose. The signals around 918 and $979 \mathrm{~cm}^{-1}$ are assigned to vibrations of $\mathrm{C}-\mathrm{H}$ and $\mathrm{C}-\mathrm{O}-$ $\mathrm{H}$, and to two anomers of fructose and glucose, respectively. The peak around $1067 \mathrm{~cm}^{-1}$ is due to the $\mathrm{C}-\mathrm{H}$ and $\mathrm{C}-\mathrm{O}-\mathrm{H}$ bending of carbohydrates and due to a minor contribution of vibration of $\mathrm{C}-\mathrm{N}$ bonds in amino acids and proteins. The peak around $1127 \mathrm{~cm}^{-1}$ is a combination of stretching vibration of $\mathrm{C}-\mathrm{O}$ and $\mathrm{C}-\mathrm{O}-\mathrm{C}$ and vibration of $\mathrm{C}-\mathrm{N}$ of proteins and amino acids. This peak is also related to deformation of $\mathrm{C}-\mathrm{OH}$ of glucose and sucrose. The signal at $1265 \mathrm{~cm}^{-1}$ is related to $\mathrm{C}-\mathrm{O}-\mathrm{H}, \mathrm{C}-\mathrm{C}-\mathrm{H}$, and $\mathrm{O}-\mathrm{C}-\mathrm{H}$ vibrations, and for fructose it is related to $\mathrm{C}-\mathrm{O}-\mathrm{C}$ cyclic alkyl ethers. The band at $1373 \mathrm{~cm}^{-1}$ is assigned to the bending of $\mathrm{C}-\mathrm{H}$ and $\mathrm{O}-\mathrm{H}$ bonds, also for glucose and sucrose. Finally, the peak at $1461 \mathrm{~cm}^{-1}$ is related to the combination of the vibration of the COO group and the bending vibration of the $\mathrm{CH}_{2}$ group. This peak also is attributed to symmetric deformation mode of $\mathrm{CH}_{2}$ in fructose and the presence of flavanols and organic acids.

\section{Conclusions}

Honey consumption gradually raises mainly because of its health benefits. However, an important issue that consumers, producers, industries, and researchers must deal with is the verification of its authenticity in terms of botanical and geographic origin. Nonetheless, adulteration cases should not be neglected. Consequently, it is urgent to develop low-cost, simple, and reliable techniques that will ensure authenticity of honey. In this regard, SPME-GC-MS based on the volatile fraction was proved to provide reliable results able to determine the authenticity of honey as far as its botanical and geographical origin. Furthermore, spectroscopic methods, namely IR and Raman, can also evaluate both botanical and geographical origins of honey. Moreover, spectroscopic techniques were also able to detect adulteration, mainly with sugar syrups. However, to interpretate the complicated results, chemometric analysis was used. In general, the above-mentioned techniques combined with chemometric analysis are a powerful tool able to "screen" honey quality and to ensure consumers its authenticity. The present review contributes to the amplification and development of a methodology for the authenticity of honey, which will allow the market to verify the label description and the quality of the product.

Author Contributions: Conceptualization, N.S.S., C.K., C.P., P.T.; methodology, N.S.S., C.K., C.P., P.T.; formal analysis, N.S.S.; investigation, N.S.S.; writing-original draft preparation, N.S.S.; 
writing-review and editing, N.S.S., M.X., P.K.R., E.K., C.K., C.P., P.T.; project administration, C.K., C.P., P.T.; funding acquisition, C.K., C.P., P.T.; supervision, P.T. All authors have read and agreed to the published version of the manuscript.

Funding: This study was co-financed by the European Regional Development Fund of the European Union and Greek national funds through the Operational Program Competitiveness, Entrepreneurship, and Innovation, under the call "RESEARCH-CREATE-INNOVATE" (Project code: T1E $\Delta \mathrm{K}-05678$, by the acronym “QuaAuthentic_GR"), awarded to P.T.

Institutional Review Board Statement: Not applicable.

Informed Consent Statement: Not applicable.

Acknowledgments: The authors acknowledge the support of this work from the European Regional Development Fund of the European Union and Greek national funds through the Operational Program Competitiveness, Entrepreneurship, and Innovation, under the call "RESEARCH-CREATEINNOVATE" (Project code: T1E $\Delta$ K-05678, by the acronym “QuaAuthentic_GR"), awarded to P.T.

Conflicts of Interest: The authors declare that they have no known competing financial interests or personal relationships that could have appeared to influence the work reported in this paper.

\section{References}

1. Bianchin, J.N.; Nardini, G.; Merib, J.; Dias, A.N.; Martendal, E.; Carasek, E. Screening of volatile compounds in honey using a new sampling strategy combining multiple extraction temperatures in a single assay by HS-SPME-GC-MS. Food Chem. 2014, 145, 1061-1065. [CrossRef]

2. Mădaş, N.M.; Mărghitaş, L.A.; Dezmirean, D.S.; Bonta, V.; Bobiş, O.; Fauconnier, M.L.; Francis, F.; Haubruge, E.; Nguyen, K.B. Volatile profile and physico-chemical analysis of acacia honey for geographical origin and nutritional value determination. Foods 2019, 8, 445. [CrossRef] [PubMed]

3. Castro-Vázquez, L.; Díaz-Maroto, M.C.; de Torres, C.; Pérez-Coello, M.S. Effect of geographical origin on the chemical and sensory characteristics of chestnut honeys. Food Res. Int. 2010, 43, 2335-2340. [CrossRef]

4. Kuś, P.M.; Jerković, I.; Marijanović, Z.; Kranjac, M.; Tuberoso, C.I.G. Unlocking Phacelia tanacetifolia Benth. honey characterization through melissopalynological analysis, color determination and volatiles chemical profiling. Food Res. Int. 2018, 106, 243-253. [CrossRef] [PubMed]

5. Alissandrakis, E.; Tarantilis, P.A.; Pappas, C.; Harizanis, P.C.; Polissiou, M. Investigation of organic extractives from unifloral chestnut (Castanea sativa L.) and eucalyptus (Eucalyptus globulus Labill.) honeys and flowers to identification of botanical marker compounds. LWT Food Sci. Technol. 2011, 44, 1042-1051. [CrossRef]

6. Da Silva, P.M.; Gauche, C.; Gonzaga, L.V.; Costa, A.C.O.; Fett, R. Honey: Chemical composition, stability and authenticity. Food Chem. 2016, 196, 309-323. [CrossRef]

7. Siddiqui, A.J.; Musharraf, S.G.; Choudhary, M.I.; Rahman, A. ur Application of analytical methods in authentication and adulteration of honey. Food Chem. 2017, 217, 687-698. [CrossRef]

8. Ciotlaus, I.; Balea, A.; Pojar-Fenesan, M.; Petean, I. Cromathographic profile of volatiles of multifloral and unifloral honey collected by apis mellifera from Transilvania, Romania. Rev. Chim. 2020, 71, 91-99. [CrossRef]

9. Devi, A.; Jangir, J.; Anu-Appaiah, K.A. Chemical characterization complemented with chemometrics for the botanical origin identification of unifloral and multifloral honeys from India. Food Res. Int. 2018, 107, 216-226. [CrossRef]

10. De Lima Morais da Silva, P.; de Lima, L.S.; Caetano, Í.K.; Torres, Y.R. Comparative analysis of the volatile composition of honeys from Brazilian stingless bees by static headspace GC-MS. Food Res. Int. 2017, 102, 536-543. [CrossRef] [PubMed]

11. Escriche, I.; Visquert, M.; Juan-Borrás, M.; Fito, P. Influence of simulated industrial thermal treatments on the volatile fractions of different varieties of honey. Food Chem. 2009, 112, 329-338. [CrossRef]

12. Kaškoniene, V.; Venskutonis, P.R.; Čeksteryte, V. Composition of volatile compounds of honey of various floral origin and beebread collected in Lithuania. Food Chem. 2008, 111, 988-997. [CrossRef]

13. Kortesniemi, M.; Rosenvald, S.; Laaksonen, O.; Vanag, A.; Ollikka, T.; Vene, K.; Yang, B. Sensory and chemical profiles of Finnish honeys of different botanical origins and consumer preferences. Food Chem. 2018, 246, 351-359. [CrossRef] [PubMed]

14. Acevedo, F.; Torres, P.; Oomah, B.D.; de Alencar, S.M.; Massarioli, A.P.; Martín-Venegas, R.; Albarral-Ávila, V.; Burgos-Díaz, C.; Ferrer, R.; Rubilar, M. Volatile and non-volatile/semi-volatile compounds and in vitro bioactive properties of Chilean Ulmo (Eucryphia cordifolia Cav.) honey. Food Res. Int. 2017, 94, 20-28. [CrossRef] [PubMed]

15. Aliaño-González, M.J.; Ferreiro-González, M.; Espada-Bellido, E.; Barbero, G.F.; Palma, M. Novel method based on ion mobility spectroscopy for the quantification of adulterants in honeys. Food Control. 2020, 114, 107236. [CrossRef]

16. Ballabio, D.; Robotti, E.; Grisoni, F.; Quasso, F.; Bobba, M.; Vercelli, S.; Gosetti, F.; Calabrese, G.; Sangiorgi, E.; Orlandi, M.; et al. Chemical profiling and multivariate data fusion methods for the identification of the botanical origin of honey. Food Chem. 2018, 266, 79-89. [CrossRef] 
17. Bianchi, F.; Mangia, A.; Mattarozzi, M.; Musci, M. Characterization of the volatile profile of thistle honey using headspace solid-phase microextraction and gas chromatography-mass spectrometry. Food Chem. 2011, 129, 1030-1036. [CrossRef]

18. Patrignani, M.; Fagúndez, G.A.; Tananaki, C.; Thrasyvoulou, A.; Lupano, C.E. Volatile compounds of Argentinean honeys: Correlation with floral and geographical origin. Food Chem. 2018, 246, 32-40. [CrossRef]

19. Stanimirova, I.; Üstün, B.; Cajka, T.; Riddelova, K.; Hajslova, J.; Buydens, L.M.C.; Walczak, B. Tracing the geographical origin of honeys based on volatile compounds profiles assessment using pattern recognition techniques. Food Chem. 2010, 118, 171-176. [CrossRef]

20. Castro-Vázquez, L.; Leon-Ruiz, V.; Alañon, M.E.; Pérez-Coello, M.S.; González-Porto, A.V. Floral origin markers for authenticating Lavandin honey (Lavandula angustifolia $\times$ latifolia). Discrimination from Lavender honey (Lavandula latifolia). Food Control 2014, 37, 362-370. [CrossRef]

21. Da Costa, A.C.V.; Sousa, J.M.B.; da Silva, M.A.A.P.; dos Garruti, D.S.; Madruga, M.S. Sensory and volatile profiles of monofloral honeys produced by native stingless bees of the brazilian semiarid region. Food Res. Int. 2018, 105, 110-120. [CrossRef]

22. Castro-Vázquez, L.; Díaz-Maroto, M.C.; González-Viñas, M.A.; Pérez-Coello, M.S. Differentiation of monofloral citrus, rosemary, eucalyptus, lavender, thyme and heather honeys based on volatile composition and sensory descriptive analysis. Food Chem. 2009, 112, 1022-1030. [CrossRef]

23. Escriche, I.; Kadar, M.; Juan-Borrás, M.; Domenech, E. Using flavonoids, phenolic compounds and headspace volatile profile for botanical authentication of lemon and orange honeys. Food Res. Int. 2011, 44, 1504-1513. [CrossRef]

24. Escriche, I.; Sobrino-Gregorio, L.; Conchado, A.; Juan-Borrás, M. Volatile profile in the accurate labelling of monofloral honey. The case of lavender and thyme honey. Food Chem. 2017, 226, 61-68. [CrossRef] [PubMed]

25. Juan-Borrás, M.; Domenech, E.; Hellebrandova, M.; Escriche, I. Effect of country origin on physicochemical, sugar and volatile composition of acacia, sunflower and tilia honeys. Food Res. Int. 2014, 60, 86-94. [CrossRef]

26. Soria, A.C.; Martínez-Castro, I.; Sanz, J. Some aspects of dynamic headspace analysis of volatile components in honey. Food Res. Int. 2008, 41, 838-848. [CrossRef]

27. Jerković, I.; Tuberoso, C.I.G.; Marijanović, Z.; Jelić, M.; Kasum, A. Headspace, volatile and semi-volatile patterns of Paliurus spina-christi unifloral honey as markers of botanical origin. Food Chem. 2009, 112, 239-245. [CrossRef]

28. Albergamo, A.; Mottese, A.F.; Bua, G.D.; Caridi, F.; Sabatino, G.; Barrega, L.; Costa, R.; Dugo, G. Discrimination of the Sicilian Prickly Pear (Opuntia Ficus-Indica L., CV. Muscaredda) According to the Provenance by Testing Unsupervised and Supervised Chemometrics. J. Food Sci. 2018, 83, 2933-2942. [CrossRef]

29. Dorota, D.; Rupert, M.; Wołosiak, R.; Bzducha-Wróbel, A.; Ścibisz, I.; Matuszewska-Janica, A. Volatiles as markers of bioactive components found in Croatian extra virgin olive oils. LWT 2021, 139, 110532. [CrossRef]

30. Gatzias, I.S.; Karabagias, I.K.; Kontominas, M.G.; Badeka, A.V. Geographical differentiation of feta cheese from northern Greece based on physicochemical parameters, volatile compounds and fatty acids. LWT 2020, 131, 109615. [CrossRef]

31. Micić, D.; Ostojić, S.; Pezo, L.; Blagojević, S.; Pavlić, B.; Zeković, Z.; Đurović, S. Essential oils of coriander and sage: Investigation of chemical profile, thermal properties and QSRR analysis. Ind. Crops Prod. 2019, 138, 111438. [CrossRef]

32. Moniruzzaman, M.; Rodríguez, I.; Ramil, M.; Cela, R.; Sulaiman, S.A.; Gan, S.H. Assessment of gas chromatography time-of-flight accurate mass spectrometry for identification of volatile and semi-volatile compounds in honey. Talanta 2014, 129, 505-515. [CrossRef]

33. Salvo, A.; Costa, R.; Albergamo, A.; Arrigo, S.; Rotondo, A.; La Torre, G.L.; Mangano, V.; Dugo, G. An in-depth study of the volatile variability of chinotto (Citrus myrtifolia Raf.) induced by the extraction procedure. Eur. Food Res. Technol. 2019, 245, 873-883. [CrossRef]

34. Šiškovič, N.; Strojnik, L.; Grebenc, T.; Vidrih, R.; Ogrinc, N. Differentiation between species and regional origin of fresh and freeze-dried truffles according to their volatile profiles. Food Control 2021, 123, 107698. [CrossRef]

35. Soria, A.C.; Martínez-Castro, I.; Sanz, J. Study of the precision in the purge-and-trap-gas chromatography-mass spectrometry analysis of volatile compounds in honey. J. Chromatogr. A 2009, 1216, 3300-3304. [CrossRef]

36. Tufariello, M.; Pati, S.; D'Amico, L.; Bleve, G.; Losito, I.; Grieco, F. Quantitative issues related to the headspace-SPME-GC/MS analysis of volatile compounds in wines: The case of Maresco sparkling wine. LWT 2019, 108, 268-276. [CrossRef]

37. Plutowska, B.; Chmiel, T.; Dymerski, T.; Wardencki, W. A headspace solid-phase microextraction method development and its application in the determination of volatiles in honeys by gas chromatography. Food Chem. 2011, 126, 1288-1298. [CrossRef]

38. Seisonen, S.; Kivima, E.; Vene, K. Characterisation of the aroma profiles of different honeys and corresponding flowers using solid-phase microextraction and gas chromatography-mass spectrometry/olfactometry. Food Chem. 2015, 169, 34-40. [CrossRef]

39. Boyce, M.C.; White, J.; Hudson, D.; Malajczuk, N.; Bennett, I.J. Characterisation of Tuber melanosporum (Perigord Black Truffle) of French and Australian Origin Using Solid-Phase Microextraction. Int. J. Chromatogr. 2018, 10, 115.

40. Costa, R.; Albergamo, A.; Arrigo, S.; Gentile, F.; Dugo, G. Solid-phase microextraction-gas chromatography and ultra-high performance liquid chromatography applied to the characterization of lemon wax, a waste product from citrus industry. J. Chromatogr. A 2019, 1603, 262-268. [CrossRef] [PubMed]

41. Cuevas-Glory, L.F.; Pino, J.A.; Santiago, L.S.; Sauri-Duch, E. A review of volatile analytical methods for determining the botanical origin of honey. Food Chem. 2007, 103, 1032-1043. [CrossRef]

42. Dias, L.G.; Hacke, A.; Bergara, S.F.; Villela, O.V.; Mariutti, L.R.B.; Bragagnolo, N. Identification of volatiles and odor-active compounds of aromatic rice by OSME analysis and SPME/GC-MS. Food Res. Int. 2021, 142, 110206. [CrossRef] 
43. Díaz, P.; Ibáñez, E.; Reglero, G.; Señoráns, F.J. Optimization of summer truffle aroma analysis by SPME: Comparison of extraction with different polarity fibres. LWT Food Sci. Technol. 2009, 42, 1253-1259. [CrossRef]

44. Farag, M.A.; Hegazi, N.; Dokhalahy, E.; Khattab, A.R. Chemometrics based GC-MS aroma profiling for revealing freshness, origin and roasting indices in saffron spice and its adulteration. Food Chem. 2020, 331, 127358. [CrossRef] [PubMed]

45. Frank, N.; Dubois, M.; Huertas Pérez, J.F. Detection of Furan and five Alkylfurans, including 2-Pentylfuran, in various Food Matrices. J. Chromatogr. A 2020, 1622, 461119. [CrossRef]

46. Hou, J.; Liang, L.; Wang, Y. Volatile composition changes in navel orange at different growth stages by HS-SPME-GC-MS. Food Res. Int. 2020, 136, 109333. [CrossRef] [PubMed]

47. Aliferis, K.A.; Tarantilis, P.A.; Harizanis, P.C.; Alissandrakis, E. Botanical discrimination and classification of honey samples applying gas chromatography/mass spectrometry fingerprinting of headspace volatile compounds. Food Chem. 2010, 121, 856-862. [CrossRef]

48. Karabagias, I.K.; Louppis, A.P.; Karabournioti, S.; Kontakos, S.; Papastephanou, C.; Kontominas, M.G. Characterization and geographical discrimination of commercial Citrus spp. honeys produced in different Mediterranean countries based on minerals, volatile compounds and physicochemical parameters, using chemometrics. Food Chem. 2017, 217, 445-455. [CrossRef]

49. WHO; FAO. Codex Alimentarius Commission and Council Directive 2001/110/EC of 20 December 2001 Relating to Honey. In Codex Alimentarius; CXS 12-1981; Codex Alimentarius Commission: Rome, Italy, 2001; pp. 1-8.

50. Aliaño-González, M.J.; Ferreiro-González, M.; Espada-Bellido, E.; Palma, M.; Barbero, G.F. A screening method based on Visible-NIR spectroscopy for the identification and quantification of different adulterants in high-quality honey. Talanta 2019, 203, 235-241. [CrossRef]

51. Huang, F.; Song, H.; Guo, L.; Guang, P.; Yang, X.; Li, L.; Zhao, H.; Yang, M. Detection of adulteration in Chinese honey using NIR and ATR-FTIR spectral data fusion. Spectrochim. Acta Part A Mol. Biomol. Spectrosc. 2020, 235, 118297. [CrossRef]

52. Arroyo-Manzanares, N.; García-Nicolás, M.; Castell, A.; Campillo, N.; Viñas, P.; López-García, I.; Hernández-Córdoba, M. Untargeted headspace gas chromatography-Ion mobility spectrometry analysis for detection of adulterated honey. Talanta 2019, 205, 120123. [CrossRef]

53. Esteki, M.; Simal-Gandara, J.; Shahsavari, Z.; Zandbaaf, S.; Dashtaki, E.; Vander Heyden, Y. A review on the application of chromatographic methods, coupled to chemometrics, for food authentication. Food Control 2018, 93, 165-182. [CrossRef]

54. Anjos, O.; Santos, A.J.A.; Paixão, V.; Estevinho, L.M. Physicochemical characterization of Lavandula spp. honey with FT-Raman spectroscopy. Talanta 2018, 178, 43-48. [CrossRef] [PubMed]

55. Ferreiro-González, M.; Espada-Bellido, E.; Guillén-Cueto, L.; Palma, M.; Barroso, C.G.; Barbero, G.F. Rapid quantification of honey adulteration by visible-near infrared spectroscopy combined with chemometrics. Talanta 2018, 188, 288-292. [CrossRef] [PubMed]

56. Jandrić, Z.; Haughey, S.A.; Frew, R.D.; McComb, K.; Galvin-King, P.; Elliott, C.T.; Cannavan, A. Discrimination of honey of different floral origins by a combination of various chemical parameters. Food Chem. 2015, 189, 52-59. [CrossRef]

57. Li, Y.; Huang, Y.; Xia, J.; Xiong, Y.; Min, S. Quantitative analysis of honey adulteration by spectrum analysis combined with several high-level data fusion strategies. Vib. Spectrosc. 2020, 108, 103060. [CrossRef]

58. Özbalci, B.; Boyaci, I.H.; Topcu, A.; Kadilar, C.; Tamer, U. Rapid analysis of sugars in honey by processing Raman spectrum using chemometric methods and artificial neural networks. Food Chem. 2013, 136, 1444-1452. [CrossRef]

59. Salvador, L.; Guijarro, M.; Rubio, D.; Aucatoma, B.; Guillén, T.; Jentzsch, P.V.; Ciobotă, V.; Stolker, L.; Ulic, S.; Vásquez, L.; et al. Exploratory monitoring of the quality and authenticity of commercial honey in Ecuador. Foods 2019, 8, 105. [CrossRef]

60. Karabagias, I.K.; Badeka, A.V.; Kontakos, S.; Karabournioti, S.; Kontominas, M.G. Botanical discrimination of Greek unifloral honeys with physico-chemical and chemometric analyses. Food Chem. 2014, 165, 181-190. [CrossRef]

61. Karabagias, I.K.; Badeka, A.; Kontakos, S.; Karabournioti, S.; Kontominas, M.G. Characterization and classification of Thymus capitatus (L.) honey according to geographical origin based on volatile compounds, physicochemical parameters and chemometrics. Food Res. Int. 2014, 55, 363-372. [CrossRef]

62. Karabagias, I.K.; Badeka, A.; Kontakos, S.; Karabournioti, S.; Kontominas, M.G. Characterisation and classification of Greek pine honeys according to their geographical origin based on volatiles, physicochemical parameters and chemometrics. Food Chem. 2014, 146, 548-557. [CrossRef] [PubMed]

63. Aykas, D.P.; Shotts, M.-L.; Rodriguez-Saona, L.E. Authentication of commercial honeys based on Raman fingerprinting and pattern recognition analysis. Food Control 2020, 117, 107346. [CrossRef]

64. Li, S.; Shan, Y.; Zhu, X.; Zhang, X.; Ling, G. Detection of honey adulteration by high fructose corn syrup and maltose syrup using Raman spectroscopy. J. Food Compos. Anal. 2012, 28, 69-74. [CrossRef]

65. Guelpa, A.; Marini, F.; du Plessis, A.; Slabbert, R.; Manley, M. Verification of authenticity and fraud detection in South African honey using NIR spectroscopy. Food Control 2017, 73, 1388-1396. [CrossRef]

66. Basalekou, M.; Pappas, C.; Tarantilis, P.; Kotseridis, Y.; Kallithraka, S. Wine authentication with Fourier Transform Infrared Spectroscopy: A feasibility study on variety, type of barrel wood and ageing time classification. Int. J. Food Sci. Technol. 2017, 52, 1307-1313. [CrossRef]

67. Feizi, N.; Hashemi-Nasab, F.S.; Golpelichi, F.; Sabouruh, N.; Parastar, H. Recent trends in application of chemometric methods for GC-MS and GC $\times$ GC-MS-based metabolomic studies. TrAC Trends Anal. Chem. 2021, 138, 116239. [CrossRef] 
68. Gianneti, V.; Boccaci Mariani, M.; Marini, F.; Torrelli, P.; Biancolillo, A. Flavour fingerprint for the differentiation of Grappa from other Italiandistillates by GC-MS and chemometrics. Food Control 2019, 105, 123-130. [CrossRef]

69. Kucharska-Ambrożej, K.; Karpinska, J. The application of spectroscopic techniques in combination with chemometrics for detection adulteration of some herbs and spices. Microchem. J. 2020, 153, 104278. [CrossRef]

70. Valasi, L.; Arvanitaki, D.; Mitropoulou, A.; Georgiadou, M.; Pappas, C.S. Study of the quality parameters and the antioxidant capacity for the Ftir-chemometric differentiation of pistacia vera oils. Molecules 2020, 25, 1614. [CrossRef]

71. Da Costa, A.C.V.; Sousa, J.M.B.; Bezerra, T.K.A.; da Silva, F.L.H.; Pastore, G.M.; da Silva, M.A.A.P.; Madruga, M.S. Volatile profile of monofloral honeys produced in Brazilian semiarid region by stingless bees and key volatile compounds. LWT 2018, 94, 198-207. [CrossRef]

72. Mottese, A.F.; Fede, M.R.; Caridi, F.; Sabatino, G.; Marcianò, G.; Calabrese, G.; Albergamo, A.; Dugo, G. Chemometrics and innovative multidimensional data analysis (MDA) based on multi-element screening to protect the Italian porcino (Boletus sect. Boletus) from fraud. Food Control 2020, 110, 107004. [CrossRef]

73. Mottese, A.F.; Albergamo, A.; Bartolomeo, G.; Bua, G.D.; Rando, R.; De Pasquale, P.; Saija, E.; Donato, D.; Dugo, G. Evaluation of fatty acids and inorganic elements by multivariate statistics for the traceability of the Sicilian Capparis spinosa L. J. Food Compos. Anal. 2018, 72, 66-74. [CrossRef]

74. Pérez-Castaño, E.; Medina-Rodríguez, S.; Bagur-González, M.G. Discrimination and classification of extra virgin olive oil using a chemometric approach based on TMS-4, $4^{\prime}$-desmetylsterols GC(FID) fingerprints of edible vegetable oils. Food Chem. 2019, 274, 518-525. [CrossRef] [PubMed]

75. Pollo, B.J.; Teixeira, C.A.; Belinato, J.R.; Furlan, M.F.; de Cunha, I.C.M.; Vaz, C.R.; Volpato, G.V.; Augusto, F. Chemometrics, Comprehensive Two-Dimensional gas chromatography and "omics" sciences: Basic tools and recent applications. TrAC Trends Anal. Chem. 2021, 134, 116111. [CrossRef]

76. Guo, T.; Li, Y.; Yong, W.; Fang, P.; Qin, Z.; Yan, A.; Dong, Y. Non-target geographic region discrimination of Cabernet Sauvignonwine by direct analysis in real time mass spectrometry withchemometrics methods. Int. J. Mass Spectrom. 2021, $464,116577$. [CrossRef]

77. Karabagias, I.K.; Badeka, A.; Kontominas, M.G. A decisive strategy for monofloral honey authentication using analysis of volatile compounds and pattern recognition techniques. Microchem. J. 2020, 152, 104263. [CrossRef]

78. Tahir, H.E.; Xiaobo, Z.; Zhihua, L.; Yaodi, Z. Comprehensive evaluation of antioxidant properties and volatile compounds of sudanese honeys. J. Food Biochem. 2015, 39, 349-359. [CrossRef]

79. Tahir, H.E.; Xiaobo, Z.; Xiaowei, H.; Jiyong, S.; Mariod, A.A. Discrimination of honeys using colorimetric sensor arrays, sensory analysis and gas chromatography techniques. Food Chem. 2016, 206, 37-43. [CrossRef]

80. Gan, Z.; Yang, Y.; Li, J.; Wen, X.; Zhu, M.; Jiang, Y.; Ni, Y. Using sensor and spectral analysis to classify botanical origin and determine adulteration of raw honey. J. Food Eng. 2016, 178, 151-158. [CrossRef]

81. Wang, X.; Yang, S.; He, J.; Chen, L.; Zhang, J.; Jin, Y.; Zhou, J.; Zhang, Y. A green triple-locked strategy based on volatile-compound imaging, chemometrics, and markers to discriminate winter honey and sapium honey using headspace gas chromatography-ion mobility spectrometry. Food Res. Int. 2019, 119, 960-967. [CrossRef]

82. D'Arcy, B.R.; Rintoul, G.B.; Rowland, C.Y.; Blackman, A.J. Composition of Australian Honey Extractives. 1. Norisoprenoids, Monoterpenes, and Other Natural Volatiles from Blue Gum (Eucalyptus leucoxylon) and Yellow Box (Eucalyptus melliodora) Honeys. J. Agric. Food Chem. 1997, 45, 1834-1843. [CrossRef]

83. Tanleque-Alberto, F.; Juan-Borrás, M.; Escriche, I. Quality parameters, pollen and volatile profiles of honey from North and Central Mozambique. Food Chem. 2019, 277, 543-553. [CrossRef] [PubMed]

84. Murray, R.A. Limitations to the use of solid-phase microextraction for quantitation of mixtures of volatile organic sulfur compounds. Anal. Chem. 2001, 73, 1646-1649. [CrossRef] [PubMed]

85. Rivellino, S.R.; Hantao, L.W.; Risticevic, S.; Carasek, E.; Pawliszyn, J.; Augusto, F. Detection of extraction artifacts in the analysis of honey volatiles using comprehensive two-dimensional gas chromatography. Food Chem. 2013, 141, 1828-1833. [CrossRef]

86. Odeh, I.; Abu-Lafi, S.; Dewik, H.; Al-Najjar, I.; Imam, A.; Dembitsky, V.M.; Hanuš, L.O. A variety of volatile compounds as markers in Palestinian honey from Thymus capitatus, Thymelaea hirsuta, and Tolpis virgata. Food Chem. 2007, 101, 1393-1397. [CrossRef]

87. Pasini, F.; Gardini, S.; Marcazzan, G.L.; Caboni, M.F. Buckwheat honeys: Screening of composition and properties. Food Chem. 2013, 141, 2802-2811. [CrossRef]

88. Špánik, I.; Pažitná, A.; Šiška, P.; Szolcsányi, P. The determination of botanical origin of honeys based on enantiomer distribution of chiral volatile organic compounds. Food Chem. 2014, 158, 497-503. [CrossRef]

89. Yang, Y.; Battesti, M.J.; Djabou, N.; Muselli, A.; Paolini, J.; Tomi, P.; Costa, J. Melissopalynological origin determination and volatile composition analysis of Corsican "chestnut grove" honeys. Food Chem. 2012, 132, 2144-2154. [CrossRef]

90. Rodríguez-Flores, M.S.; Falcão, S.I.; Escuredo, O.; Seijo, M.C.; Vilas-Boas, M. Description of the volatile fraction of Erica honey from the northwest of the Iberian Peninsula. Food Chem. 2021, 336, 127758. [CrossRef] [PubMed]

91. Chen, L.; Xue, X.; Ye, Z.; Zhou, J.; Chen, F.; Zhao, J. Determination of Chinese honey adulterated with high fructose corn syrup by near infrared spectroscopy. Food Chem. 2011, 128, 1110-1114. [CrossRef]

92. Shiddiq, M.; Zulkarnain, Z.; Asyana, V.; Aliyah, H. Identification of Pure and Adulterated Honey Using Two Spectroscopic Methods. J. Phys. Conf. Ser. 2019, 1351, 012022. [CrossRef] 
93. Li, S.; Zhang, X.; Shan, Y.; Su, D.; Ma, Q.; Wen, R.; Li, J. Qualitative and quantitative detection of honey adulterated with high-fructose corn syrup and maltose syrup by using near-infrared spectroscopy. Food Chem. 2017, 218, 231-236. [CrossRef]

94. Yang, X.; Guang, P.; Xu, G.; Zhu, S.; Chen, Z.; Huang, F. Manuka honey adulteration detection based on near-infrared spectroscopy combined with aquaphotomics. LWT 2020, 132, 109837. [CrossRef]

95. Das, C.; Chakraborty, S.; Acharya, K.; Bera, N.K.; Chattopadhyay, D.; Karmakar, A.; Chattopadhyay, S. FT-MIR supported Electrical Impedance Spectroscopy based study of sugar adulterated honeys from different floral origin. Talanta 2017, 171, 327-334. [CrossRef]

96. Mail, M.H.; Ab Rahim, N.; Amanah, A.; Khawory, M.H.; Shahudin, M.A.; Seeni, A. FTIR and elementary analysis of Trigona honey, Apis honey and adulterated honey mixtures. Biomed. Pharmacol. J. 2019, 12, 2011-2017. [CrossRef]

97. Se, K.W.; Ghoshal, S.K.; Wahab, R.A.; Ibrahim, R.K.R.; Lani, M.N. A simple approach for rapid detection and quantification of adulterants in stingless bees (Heterotrigona itama) honey. Food Res. Int. 2018, 105, 453-460. [CrossRef]

98. Riswahyuli, Y.; Rohman, A.; Setyabudi, F.M.C.S.; Raharjo, S. Indonesian wild honey authenticity analysis using attenuated total reflectance-fourier transform infrared (ATR-FTIR) spectroscopy combined with multivariate statistical techniques. Heliyon 2020, 6, e03662. [CrossRef] [PubMed]

99. Ghanavati Nasab, S.; Javaheran Yazd, M.; Marini, F.; Nescatelli, R.; Biancolillo, A. Classification of honey applying high performance liquid chromatography, near-infrared spectroscopy and chemometrics. Chemom. Intell. Lab. Syst. 2020, 202, 104037. [CrossRef] 